\title{
MASTER \\ Western Gas Sands Project \\ Status Report
}
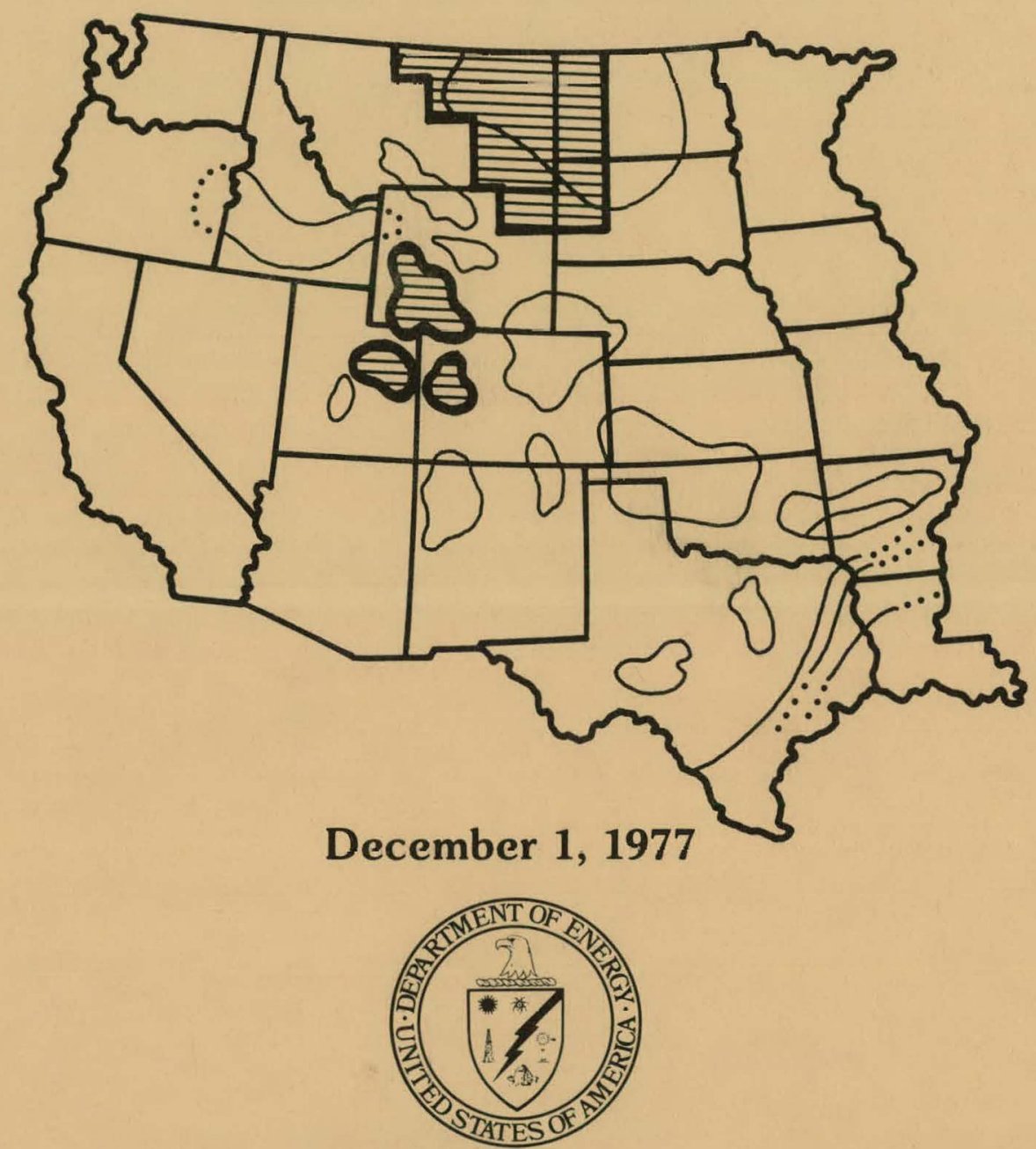

Prepared for

U.S. Department of Energy

Bartlesville Energy Research Center

Charles $\mathrm{H}$. Atkinson

Project Manager

Compiled by CER Corporation

Las Vegas, Nevada

Contract EY-76-C-08-0655 


\section{DISCLAIMER}

This report was prepared as an account of work sponsored by an agency of the United States Government. Neither the United States Government nor any agency Thereof, nor any of their employees, makes any warranty, express or implied, or assumes any legal liability or responsibility for the accuracy, completeness, or usefulness of any information, apparatus, product, or process disclosed, or represents that its use would not infringe privately owned rights. Reference herein to any specific commercial product, process, or service by trade name, trademark, manufacturer, or otherwise does not necessarily constitute or imply its endorsement, recommendation, or favoring by the United States Government or any agency thereof. The views and opinions of authors expressed herein do not necessarily state or reflect those of the United States Government or any agency thereof. 


\section{DISCLAIMER}

Portions of this document may be illegible in electronic image products. Images are produced from the best available original document. 
THIS PAGE

\section{WAS INTENTIONALLY LEFT BLANK}


This report was prepared as an account of work sponsored by the United States Government. Neither the United States nor the United States DOE, nor any of their employees, nor any of their contractors, subcontractors, or their employees, makes any warranty, express or implied, or assumes any legal liability or responsibility for the accuracy, completeness, or usefulness of any information, apparatus, product or process disclosed, or represents that its use would not infringe privately owned rights.

Available from the National Technical Information Service, U.S. Department of Commerce, Springfield, Virginia 22161.

\begin{tabular}{|c|c|c|c|c|c|c|c|c|c|c|c|}
\hline \multirow[b]{2}{*}{$\begin{array}{l}\text { Page } \\
\text { range }\end{array}$} & \multicolumn{11}{|c|}{$\begin{array}{l}\text { NATIONAL TECHNICAL INFORMATION SERVICE PAPER COPY PRICES } \\
\text { EFFECTIVE JAN. } 1.1976\end{array}$} \\
\hline & $\begin{array}{c}\text { Domestic } \\
\text { price }\end{array}$ & $\begin{array}{l}\text { Page } \\
\text { range }\end{array}$ & $\begin{array}{l}\text { Domestic } \\
\text { price }\end{array}$ & $\begin{array}{l}\text { Page } \\
\text { range }\end{array}$ & $\begin{array}{l}\text { Domestic } \\
\text { price }\end{array}$ & $\begin{array}{l}\text { Page } \\
\text { range }\end{array}$ & $\begin{array}{l}\text { Domestic } \\
\text { price }\end{array}$ & $\begin{array}{l}\text { Page } \\
\text { range }\end{array}$ & $\begin{array}{l}\text { Domestic } \\
\text { price }\end{array}$ & $\begin{array}{l}\text { Page } \\
\text { range }\end{array}$ & $\begin{array}{l}\text { Domestic } \\
\text { price }\end{array}$ \\
\hline 001.025 & $\$ 3.50$ & $126 \cdot 150$ & $\$ 6.00$ & $251-275$ & $\$ 9.00$ & 376.400 & $\$ 10.75$ & 501.525 & $\$ 12.75$ & $701 \cdot 800$ & $\$ 18.75$ \\
\hline 026.050 & $\$ 4.00$ & $151 \cdot 175$ & $\$ 6.75$ & $276-300$ & $\$ 9.25$ & $401 \cdot 425$ & $\$ 11.00$ & $526-550$ & $\$ 13.00$ & $801 \cdot 900$ & $\$ 21.25$ \\
\hline 051.075 & $\$ 4.50$ & 176.200 & $\$ 7.50$ & $301-325$ & $\$ 9.75$ & $426-450$ & $\$ 11.75$ & 551.575 & $\$ 13.50$ & $9 n 1.1000$ & $\$ 23.75$ \\
\hline $076 \cdot 100$ & $\$ 5.00$ & 201.225 & $\$ 7.75$ & $326-350$ & $\$ 10.00$ & 451.475 & $\$ 12.00$ & $576-600$ & $\$ 13.75$ & $1001 \cdot 1100$ & $\$ 28.25$ \\
\hline $101 \cdot 125$ & $\$ 5.50$ & $226 \cdot 250$ & $\$ 8.00$ & $351-375$ & $\$ 10.50$ & 476.500 & $\$ 12.50$ & $601 \cdot 700$ & $\$ 16.25$ & $\$ 101-1200$ & $\$ 32.75$ \\
\hline
\end{tabular}

For additional pages, add $\$ 4.50$ for each beginning 100 pages. Add $\$ 2.50$ per copy for foreign price.

Microfiche $\$ 3.00$ (domestic) $\$ 4.50$ (foreign).

Printed copy \$5.(10).

This report was prepared as an account of work sponsored by the United States Govemment. Neither the United States nor the United States Department of Energy, nor any of their employees, nor any of their contractors, subcontractors, or their employees, makes any warranty, express or implied, or assumes any legal liability or responsibility for the acculacy, comploconess or usefutness of any information, apparatus, product or process disclosed, or represents that its usc would not infringe privately owned rights.

ii. 


\section{CONTENTS}

$\underline{\text { Page }}$

1.

SUMMAR

2.

3. RESOURCE ASSESSMENT .................... 5

3.1 U.S. Geological Survey Activities .......... 5

3.2 Coring Program . . . . . . . . . . . . . . . 6

3.3 Study of Basin Activities ............. . 7

4. RESEARCH AND DEVELOPMENT BY ENERGY RESEARCH CENTERS

AND NATIONAL LABORATORIES . . . . . . . . . . . 13

4.1 Bartlesville Energy Research Center . . . . . . . . 13

4.2 Lawrence Livermore Laboratory . . . . . . . . . . 15

4.3 Sandia Laboratories . . . . . . . . . . . . . 16

4.4 U.S. Geological Survey . . . . . . . . . . . . . . 24

4.5 U.S. Geological Survey/Menlo Park . . . . . . . . . 24

5. FIELD TESTS AND DEMONSTRATIONS . . . . . . . . . . 25

5.1 Background .................... 25

5.2 CER Corporation ................. 29

5.3 Colorado Interstate Gas Company . . . . . . . . . . 31

5.4 Gas Producing Enterprises Inc. . . . . . . . . . . . 33

5.5 Mobil Research and Development Corporation . . . . . . 46

5.6 Pacific Transmission Supply Company . . . . . . . . 57

5.7 Rio Blanco Natural Gas Company . . . . . . . . . . 59 


\section{FIGURES}

$\underline{\text { Page }}$

FIGURE $3-1$ TARGET BASINS WITH WELLS OF INTEREST LOCATED . . . 11

FIGURE 4-1 SEISMIC SOURCE LOCATIONS PROJECTED ON HORIZONTAL PLANE . . . . . . . . . . . 18

FIGURE 4-2 SEISMIC SOURCE LOCATIONS PROJECTED ON PLANE N80 E . 19

FIGURE 4-3 SECOND FRACTURE - WELDED TUFF . . . . . . . . 20

FIGURE 4-4 FRESSURE RECORD - HP TRANSDUCER . . . . . . . . . 22

FIGURE 4-5 PRELIMINARY FIELD PRESSURE RESULTS - AMERADA BOMB . 23

FIGURE 5-1 FLOW RATE PERFORMANCE OF NATURAL BUTTES NO. 14 WELL . 41

FIGURE 5-2 FLOW RATE PERFORMANCE OF NATURAL BUTTES NO. 18 WELL . 42

FIGURE 5-3 FLOW RATE PERFORMANCE OF NATURAL BUTTES NO. 19 WELL 443

FIGURE 5-4 FLOW RATE PERFORMANCE OF NATURAL BUTTES NO. 20 WELL . 44

FIGURE 5-5 SCHEMATIC OF MOBIL F-31-13G WELL SHOWING $3 A$ and

3B ZONES .................... 48

FIGURE 5-6 SCHEMATIC OF MOBIL F-31-13G WELL . . . . . . . . 49

FIGURE 5-7 PCU \#31-13 PBU (BEFORE BREAKDOWN) ZONE 1 . . . . . 50

FIGURE 5-8 PCU \#31-13 PBU (BEFORE FRAC) . . . . . . . . . . 51

FIGURE 5-9 PCU \#31-13 PBU (AFTER FRAC) . . . . . . . . . . 52

FIGURE 5-10 PCU \#31-13 PBU (BEFORE FRAC) ZONE $3 . . . . . . . . .53$

FIGURE 5-11 PCU \#31-13 PBU (AFTER FRAC) ZONE 3 . . . . . . . 54

FIGURE 5-12 PCU \#31-13 PBU (BEFORE FRAC) ZONE 4A........ 55

FIGURE 5-13 PCU \#31-13 PBU (BEFORE FRAC) ZONE 4B......... 56 


\section{TABLES}

Page

TABLE 5-1 MHF CONTRACT LOCATIONS AND FRAC DATA . . . . . . . 26

TABLE 5-2

COMPARISON OF CORE INTERVALS TO LOG INTERPRETED

POROSITY ZONES - NATURAL BUTTES 21 . . . . . . 35

TABLE 5-3 DESCRIPTION OF CORES RECOVERED FROM THE

NATURAL BUTTES 21 WELL . . . . . . . . . . . . . 36 


\section{SUMMARY}

This is the fourth issue of the Western Gas Sands Project Status Report, compiled by CER Corporation for C.H. Atkinson, Bartlesville Energy Research Center, the Project Manager. Additional background information can be obtained by referring to the September and November issues (NVO/ 0655-100 and NVO/0655-101), available from CER Corporation, or the National Technical Information Service. There was no report issued for the month of October.

This issue compiles information on many of the pertinent activities which have been, and are being undertaken in the low permeability gas sands in the western United states and includes information and status reports on new developments.

C.H. Atkinson, although continuing to report to the Bartlesville Energy. Research Center, has established an office at the Department of Energy's (DOE) Nevada Operations office (NV) in Las Vegas, the project's primary contracting office.

The Western Gas Sands Project Plan, Project Implementation Plans, Project Plan Document FY 78 and the Quarterly Basin Activities Report are in various stages of preparation.

Information gathering by the U.S. Geological Survey (USGS) of the initial data base for many of the project activities is continuing. Some base maps are complete and field investigations in the principal areas of interest are being conducted. Investigation of tight gas sands with scanning electron microscope, $x$-ray diffraction techniques and an $\mathrm{x}$-ray spectrometer is proceeding.

Research and Development by Energy Research Centers and National Laboratories funded by DOE has been directed toward the development of new tools and instrumentation systems, rock mechanics experiments, mathematical modeling and data analysis.

The positive results of system development and data analysis techniques by Sandia and USGS/Menlo Park in determining fracture orientation have been very encouraging.

The Field Test and Demonstrations section reports primarily on joint Government/Industry experiments.

The Uinta Basin in Utah and Piceance Basin in Colorado have active massive hydraulic fracturing (MHF) experiments in the Upper Cretaceous tight gas formations. These are:

Gas Producing Enterprises (GPE) Natural Buttes No. 14, 18, 19, 20,21 , and 22

Mobil Research and Development F-31-13G

Rio Blanco Natural Gas 498-4-1 
Colorado Interstate Gas Company has been awarded a contract to determine if productivity in low permeability reservoirs can be improved by reducing the interstitial water saturation. The project is scheduled to begin in January 1978.

All of the MHF wells, with the exception of the Pacific Trarsmission well, have been fractured as planned. The Mobil and GPE No. 14, 18 and 20 wells show significant improvement, compared to the original flow rates. GPE No. 21 has been cored and logged. The Mobil well is to be produced to sales during the winter, after which, additional sands will be tested for MHF treatment. The Rio Blanco Natural Gas well was fractured on November 30.

Sandia Laboratories is continuing their research program in hydraulic fracturing at DOE's Nevada Test Site (NTS). Results from the mineback investigation have demonstrated how different geological features affect fracture growth. 


\section{PROJECT MANAGEMENT}

A Western Gas Sands Project (WGSP) has been established and C.H. Atkinson is the designated Project Manager. Although continuing to report to BERC, he has established an office at DOE's Nevada Operations Office, the project's primary contracting office.

A project plan has been completed and distributed. Copies can be obtained through C.H. Atkinson. It is anticipated that a revised version will be issued, taking into account data being developed in the current study of enhanced gas recovery strategies being conducted by Lewin \& Associates.

Several defining documents are being prepared for the Western Gas Sands Project. They are:

$$
\begin{aligned}
& \text { Project Implementation Plan } \\
& \text { Project Plan Document FY } 78
\end{aligned}
$$

The Project Plan Document FY 78 draft is being reviewed and will be published early in FY 78. The Project Implementation Plan is in the early stages of preparation. The framework has been established and it will be completed in early FY 78 .

A proposal from the Mitchell Energy Company regarding MHF tests in the Cotton Valley Trend, East Texas, is still being reviewed.

Activity has been initiated to provide input to the 1977 Fossil Energy Program Report. This report is intended to provide information on the Department of Energy's Research and Development work in fossil energy technology.

Additional reporting procedures have been established which will provide weekly information to BERC on any project technical achievements. Meetings, special events or proposed talks which occur in the next 60 days and which would be of interest to washington, D.C. will also be included as will1 any new contrart signing.

Meetings with technical people in BERC and USGS last month have established some of the requirements needed for the WGSP's coring program. Additional input will be obtained in December and a coordinating meeting will be held in January to establish priorities for the use of an anticipated limited supply of core. A document on the core analysis program will subsequently be published.

Project files containing available raw data and published reports on each task are being established. Missing information will be requested from the contractors. This file will be available to industry at CER Corporation's office in Las Vegas, Nevada for their perusal. Extensive 
reproduction of raw data is not expected but will be furnished, at cost, upon request. Copies of available reports or minor reproduction requests will be furnished at no charge.

Monitoring of the various field project activities will be continued with trips to the Gas Producing Enterprises and Mobil sites for observing logging and iracture treatment operations.

The USGS has prepared a Bibliography on low permeability natural gas reservoirs of the Northern Great Plains. It is open file report No. 77-391. Other reports, published or in preparation are listed below.

HANSON, M.F., naffex, R.J., Ander.i,n, G.D., Heard, H.C., Tu:hesseri, K.A., Montan, D.N., Knutson, C.F., "LLL Gas Stimulation Frogrul, Quarterly Progress Report, April through June 1977," UCKL 50036-77-2, 24 pp., August, 1977.

TY...R, L.D., Vullerdorf, W.C., Northrop, D.A., "In situ Fxamination of Hydraulir Fractures," Sandia Laboratories. (In Prep)

WOOD, M.D., King, N.E., "Interpretation of Tilt Monitoring Experiments Associated with Massive Hydraulic Fracturing of Devonian Shale Near Huntington, West Virginia," U.S. Geological Survey/Menlo Park. (In Prep)

WOOD, M.D., King, N.E., "Interpretation of Tilt Monitoring Experiments Associated with Massive Hydraulic Fracturing of the Muddy J Sandstone of Wattenberg, Colorado," U.S. Geological Survey/Menlo Park. (In Prep)

WOOD, M.D., King, N.E., "Interpretation of Tilt Monitoring Experiments Associated with Hydraulic Fracturing of Green River shale, Rock Spring, Wyoulng," U.S. Geological Survey/Menlo Park. (In Prep)

Reports by CER Corporation in preparation include:

"Core Analysis Program"

"FY 78 Plan"

"Project Implementation Plan"

"Quarterly Report - Basin Activities"

"Stat.us Report - January"

Lawrence Livermore Laboratory (LLL) has a report in the pre-publication stage that discusses the available knowledge on rock geometry and rock mechanics of the western tight gas sands. 


\section{RESOURCE ASSESSMENT}

Resource assessment includes geological and geophysical studies to understand the resource base. The majority of the resource assessment work is being performed by the USGS. There are other activities, however, which provide data input and support to their work, primarily in the area of field tests, obtaining core samples, and special core tests.

\subsection{U.S. Geological Survey Activities}

\section{U.S. Geological Survey activities follow:}

USGS has sampled and described core from the CER RB-E-01, Sec 14, T3S, R98W in the Piceance Basin, Colorado. Material was taken for heavy mineral, geochemical, X-ray, petrographic and paleontologic anal.ysis. The core was plugged for additional reservoir analysis and scanning electron microscope study. The rocks described have now been correlated as Upper Cretaceous Companian and Maestrichtian in age.

Preparation and final drafting of oil and gas chart cross sections in Piceance and Uinta Basins is to continue and plans to publish two charts by early 1978 are being made.

A cleaning up of the Greater Green River Basin well penetration computer printout maps is being completed. Maps will be available in open files.

USGS has acquired enhanced IANDSAT imagery (4 scenes) from USGS EROS Data Center, of areas in the Green River Basin and Northern Great Plains Province. They are now experimenting with photo processing to achieve optimum scale and techniques for lineament analysis.

The preparation of twenty regional E-log cross sections and various rock studies associated with the four study areas is being pursued.

Work is being done to prepare papers for oral presentations on "Shaly Sand Cross-Plot Analyses Using a Portable Calculator" and "Stratigraphy of the Mesaverde Group and Occurrence of Natural Gas in Northwest Colorado."

They are laying out cross sections to tie areas of shallow gas production from the tight reservoirs in southeastern Alberta to Bowdoin Field in rorth central Montina.

C.H. Atkinson and Gail Moore, DOE, and G. Luetkehans, CER were given a tour of USGS facilities and equipment being applied to western gas sand resource analysis. 


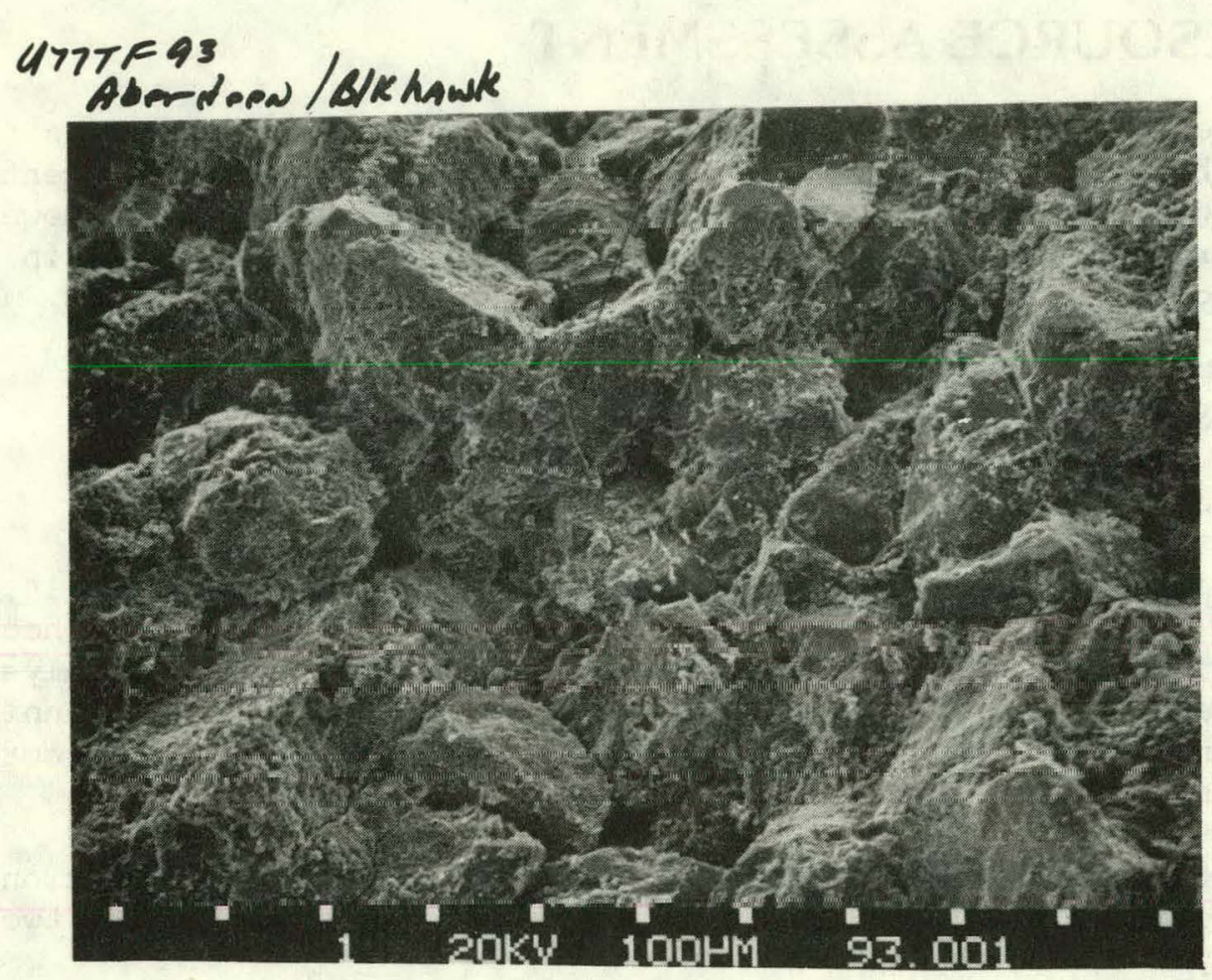

The above scanning electron photomicrograph (SEM) was taken by C.W. Keighin, USGS, and shows fine sand grains with small pore throats (between grains) coated with illite clay and minor amounts of chlorite clay. The sample is from tight sands in southern Uinta Basin, Utah. The SEM work, coupled with X-ray diffraction techniques and $\mathrm{x}$-ray spectrometer probe work identifies clays in pore throats versus wholerock clay contents. The nature of clays in pore throats is much more critical to recovery technology than clay in weathered rock and mineral fragments. Samples investigated so far have shown that these clays differ in the sands of interest to the Western Gas Sands Project and this difference could be an important factor in the design of stimulation treatments.

\subsection{Coring Program}

A core acquisition and analysis program is currently being developed. Input from the various entities who will be working on the cure program has been requested and will be available in December. An example of some of the analysis to be carried out is contained in the response by USGS; a portion of which is shown as follows: 
TYPE OF ANALYSIS AND IITHOLOGY

Thin section (sandstone)

Scanning electron microscope (SEM) (sandstone)

Cation exchange (sandstone)

X-Ray (shale and sandstone)

Micropaleontology (shale)

Organic geochemistry

(shale and siltstone)

Sedimentary structure, paleoenvironmental study and photography (permanent rosord)
AMOUNT OF CORE NEEDED

\pm I" chip

1" chip

2" $x$ 3" sample

$\pm 2 " x 3^{\prime \prime}$ sample

I" 2 " 3" sample

$\pm 2 " \times 3 "$ sample

complete slab or core, usuall.y ahnut 1 " thick.

It is important to note that the above chips and samples would probably be widely spaced and be taken when rock type changed. Several might be taken in a thick sand or shale section. For example, a uniform sandstone $10 \mathrm{ft}$ thick would probably only need one 2" $x$ 3" sample for thin section-SEM and one $2 " \times 3 "$ for cation exchange $\mathrm{x}$-ray. If the sand was $50 \mathrm{ft}$ thick, two or three intervals may be sampled.

Because there will not be enough core for the various measurements, a coordination meeting will be held in January to establish priorities and procedures for core distribution. A report outlining the acquisition, handling, distribution and analysis of the available cores, will be published. Regional sites will be identified in this report although specific site selection will depend upon negotiations with Individual operators in the general designated areas.

Substantial core was recovered in GPE's Natural Buttes 21 well, and the details are shown in section 5.4.2.

\subsection{Study of Basin Activities}

Monitoring of the drilling and testing activities in the four main study areas is continuing. Figure 3-1 shows the four areas with recent wells of interest to the WGSP located by numbered callouts. The 
following is a brief resume of the study area activities. A detailed quarterly report on each area is presently being prepared.

\subsubsection{Piceance Basin}

Activity in the Piceance Basin is concentrated into two major areas. In the western part of Rio Blanco County, Northwest Exploration, Twin Arrow, Tipperary Oil, Fuel Resources Development, Chancellor and Ridgeway are all active in the Cathedral, Dragon Trail and Lower Horse Draw Fields. Their objectives are the Mancos " $B$ " or Emery zones. Currently, there are about 60 of these tests in progress. Production from these wells, utilizing an average frac size of 175,000 lbs of sand, is about 400 MCFD. To the south, Tipperary Oil and American Resources Management are active in the South Douqlas Creek and Thunder Fields with the objective being the Mancos "B" zones.

The other major activity center is the Plateau Field of eastern Mesa County. Operators here are Flying Diamond Oil, Äpache Corp., and Norris Oil. The primary objectives are the Upper Cretaceous Cozzette and Corcoran sands at depths from 3,000 to 5,000 ft. There are approximately 10 ongoing tests in this area. Norris Oil has two wells with comingled Rollins, Cozzette and Corcoran production (callout 1). Flying Diamond has three wells producing from the Rollins, Cozzette and corcoran with an average initial production of 460 MCFD utilizing about 164,000 lbs of sand on each well.

Another important area is Gunnison County, where Ralston $O$ \& $G$ has four Mancos tests planned, and one well which has comingled Cozzette and Corcoran production. In Rio Blanco County, Mobil and American Resources Management are also testing the wasatch zone in the Piceance Creek Dome area and to the north in the Powder Wash Field.

\subsubsection{Greater Green River Basin}

Sweetwater County is the site of the most extensive drilling activity in the Greater Green River Basin. Major operators in the area are Amoco Production, Davis oil and Marathon oil. The Mesaverde, or specific formations within this group are receiving the most attention from operators in the County. Presently, about 65 Mesaverde tests are in progress. The initial production varies from 400 MCFD to over 2,000 MCFD, using frac treatments of 40,000 to over $200,000 \mathrm{lbs}$ of sand.

Drilling activity in Sweetwater County includes tests for the Dakota, Lewis, and Mesaverde. Wildcats have been staked by Davis oil and Marathon Oil for the Dakota, located northwest of Frontier production in Six Mile Spring Field, and Mesaverde, two miles south of Siberia Ridge Field. Davis Oil has a well with Lewis production in an area 
that previously produced from the Almond $(9,115-9,127 \mathrm{ft})$ at 3,600 MCFD, utilizing a frac of 85,000 lbs of sand.

Lincoln County is the site of significant Frontier testing. Amoco has nine Frontier tests in the depth range of $11,225-13,400 \mathrm{ft}$, in all stages of progress and Pacific Transmission Supply has five wells they are preparing to frac.

The fields with significant activity are Whiskey Buttes, Fontenelle and La Barge. Pacific Transmission Supply has a Fontenelle well fraced with 1,000,000 lbs of sand that is presently shut in (callout 2).

Moffat County, Colorado, comprises the southern most area of the Greater Green River Basin. Three wells have been staked in the Powder Wash Field for Ft. Union sand exploration. Anadarko Production is testing Almond sands located north of the Blue Gravel Field at the eastern edge of the County.

Sublette County makes up the northern extension of the Greater Green Rivrer Basin. Cahot and Relco Petroleum are testing the Mesaverde in the La Barge and Tip Top Field areas. Birch Creek and Pinegrove Fields are the sites of Frontier exploration by Petro-Search Exploration and Chevron. One 8,100 ft Frontier test by Mobil Oil in Tip Top Field had an initial production flow of 40,000 MCFD but no frac size was given. Belco Petroleum is testing the Almy in Rueben Field and a Ft. Union test has been staked by Chandler and Associates, northwest of Bald Mountain Field which produces from the Frontier. Pacific Transmission Supply and Rainbow Resources are testing the Frontier at the northern most points of Sublette County.

\subsubsection{Northern Great Plains Province}

Activity in the northern area of the Northern Great Plains Province is concentrated in the Bowdoin Dome of Phillips and Valley Counties and the Bearpaw Arch of Blaine, Chouteau and Hill Counties.

In Phillips County, Joseph C. Paine and Associates have fourteen wells producing from the Bowdoin and Phillips sands at about 1,351 - 1,858 ft. The average initial production flow (IPF) is $633 \mathrm{MCF}$ with a frac size of about 35,000 lbs of sand plus acid. Shenandoah oil has seven unnamed tests proposed in the Bowdoin Field and Joseph C. Paine has an additional five tests scheduled north of Bowdoin Field.

West of the Bowdoin Field in Chouteau County, J. Burns Brown is testing the Eagle in the Bullwacker Field, while wise Oil is producing 1,342 MCFD from the Eagle at 1,644 - 1,682 ft . 
John Lyon and others have scheduled two Eagle sand probes in a thirteen well gas development program in the Battle Creek area of northern Blaine County. Preliminary production information indicates at least one weil is capable of a 2,000 MCFD. About 40 miles to the southwest, Tricentrol U.S. has scheduled eight additional Eagle wells in the Bullhook gas unit.

The most significant event in the southern area is the opening of the first gas field in South Dakota. The discovery was made by Jerry McCutchin Jr. in Harding County. The well flows 980 MCFD from the Shannon through perforations $1,405-1,41 . \mathrm{ft}$. The discovery gives South Dakota both its first gas well and its first production above Pennsylvanian. The nearest production from the shannon is in Montana's Pumpkin Creek gas field, 90 miles to the west. Thee rigs scheduled to begin drilling in the field have temporarily curtailed work due to sever weather.

\subsubsection{Uinta Basin}

Activity in the Uinta Basin is concentrated almost solely in the Natural Buttes unit of Uintah County. Major operators are Belco Petroleum, Gas Producing Enterprises, Continental Oil, and Pacific Transmission Supply. Belco Petroleum has nine wells producing from the wasatch using sand emulsion fractures. The average IPF is 2,700 MCFD (callout 3). In southeastern Uintah County, Taiga Energy has staked two Mancos tests, where production has normally been from the wasatch. At present, there are about 60 wells proposed, recently drilled, or recently completed in this basin, which represents a significant increase over last month.

Other activity concerns the testing of the Wasatch zone in Altamont, Bluebell, and Starvation Fields in Duchesne County. It is also interesting to note that Chevron is investigating the Green River Formation at Red Wash Field in Uintah County.

\subsubsection{Well Information}

The following is specific information on the well callouts on Figure 3-1.

Gallout 1 Norris Dil

21-2 Federal

Ser. 2.1, Tוns, R96W

Mesa County, Colorado

Plateau Field

Rollins, Cozzette and Corcoran Production

$(2,997-3,082,3,310-3,337,3,448-3,541)$

Development Gas Well

Frac: 89,000 lbs sand; 94,000 lbs sand; 162,000 lbs sand w/acid

IPF : 1,647 MCFD 


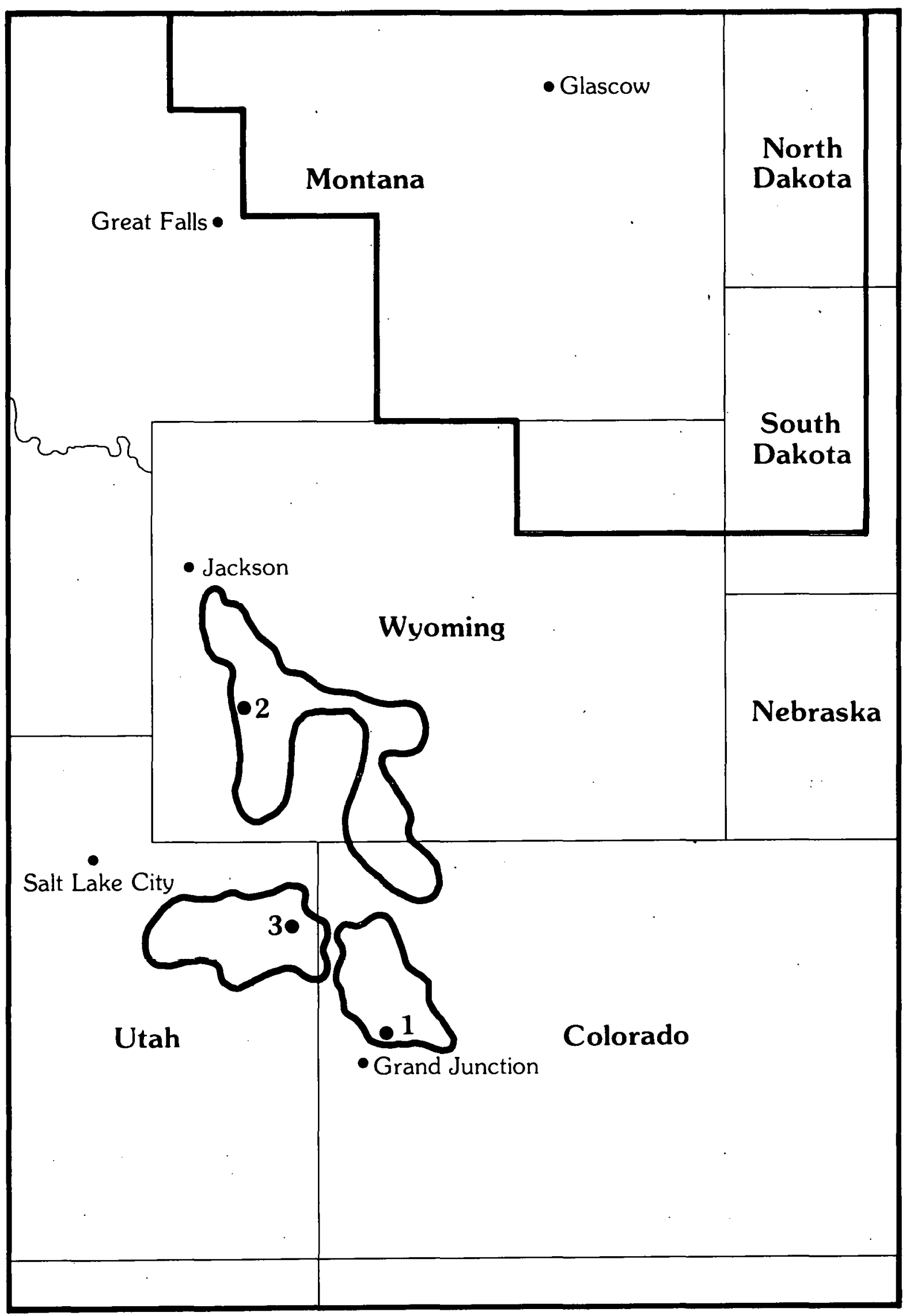

FIGURE 3-1 TARGET BASINS WITH WELLS OF INTEREST LOCATED 
Callout 2 Pacific Transmission Supply

13-9 Federal

Sec 9, T25N, RII2W

Lincoln County, Wyoming

Fontenelle Field

Frac: 1,000,000 lbs sand

Frontier Test $(8,627)$ - testing

\section{Callout 3 Belco Petroleum}

820 B Natural Buttes Unit

Sec 20, T9S, R22E

Uintah County, Utah

Natural Buttes Field

Wasatch Production $(5,152-6,387)$

Development Gas Well

Frac: 45,000 gal gel, 78,000 $\mathrm{lbs}$ sand

IPF : 1,875 MCFD 


\title{
4. RESEARCH AND DEVELOPMENT BY ENERGY RESEARCH CENTERS AND-NATIONAL LABORATORIES
}

\subsection{Bartlesville Energy Research Center (BERC)}

\author{
4.1.1 Improved Pressure Coring System
}

Sandia Laboratories is designing a coring system to cut a core with minimum drilling fluid invasion and to seal the core barrel downhole, allowing the sample to be recovered with the formation fluids and reservoir pressure intact. The system will include a pilot bit, a full gauge bit, a sealing core barrel, and will utilize a non-invading, non-freezing gel material to surround the core, preventing mud filtrate invasion.

A subcontract has been let with Maurer Engineering for the preparation of core barrel designs. Sandia has selected gel materials to test for their non-invading qualities. Also, a pressure-temperature test cell has been set up to determine the amount of invasion which would occur under a $150^{\circ} \mathrm{C}$ and 1,000 psi environment.

Two of the typical fluids to be tested are Dow Corning 200, a dimethyl siloxane, and FS-1265, a fluorisilicone compound. Both are insoluble in water and oil, have nearly constant properties from $-40^{\circ}$ to $204{ }^{\circ} \mathrm{C}$ and are available in viscosities up to 100,000 Centistokes. These, and other gels, will be tested in the presence of granite, limestone and sandstone.

\subsubsection{Measurements of Formation Characteristics for Western Tight} Gas Sands

The analysis of the properties discussed in the previous status report is being re-evaluated since it has been determined that funding is inadequate. Contract work on all the necessary interrelated tasks is being evaluated and a priority basis of selection is being investigated. It is unlikely that the concept of predicting in situ stress by measuring core relaxation can be pursued until FY 79 funds are available.

\subsubsection{Interface Corductivity Effects}

A literature search on interface conductivity effects completed during the month has revealed divided opinions among investigators. Some attribute the higher than expected bulk rock conductivity, which occurs at low formation water conductivity, to a cation exchange phenomenon facilitated by the presence of clay or shale in the rock pores. Other investigators have found increased conduction on clean sands which is attributed to a double layer interface conductivity mechanism and is 
confined to the surface of the rock pores. Evidence indicates both effects are probably present in the western gas sands.

Surface area measurements of samples in the 0.1 to $0.01 \mathrm{md}$ range have been made to test the apparatus. These tests have not been completed and the results will be reported next month. Other apparatus for resistivity measurements are being designed and assembly will begin next month.

\subsubsection{Mapping and Contouring Formation Water Resistivity}

After selecting the Uinta Basin for preliminary scrutiny, geologic background information on strata; structures and published information on known oil and/or gas fields has been requested along with base maps of wells drilled and under production in the basin. Copies of all water analyses have been obtained and the data is presently being tabulated. Contracts with regards to information retrieval have been signed with the USGS, Denver; CER in Las Vegas; the Utah Geological and Mineralogical Survey and others. As requested data and information arrives, it will be tabulated, mapped and correlated.

\subsubsection{Logging Techniques and Interpretations}

A contract with Texas $A \& M$ is under consideration to make neutron and acoustic measurements on cores to be recovered from western gas sands projects. This will involve a study of acoustics and neutron logs run in western tight gas sands to improve understanding of the interpretation techniques related to their application to specific tight gas formations.

\subsubsection{Rock-Fluid Interaction}

A comprehensive literature search was initiated for references relating to "Rock-Frac Fluid Interactions" concerned with low permeability sandstone formations. Some 55 to 60 papers were collected relating to fracturing, fracture flulds, fluid-loss additives, fracture conductivity, etc.

A preliminary design of a proposed high-pressure fluid flow experiment with fracture fluids was completed. The major components for the new laboratory equipment were determined in view of use for several other similar experiments with minor design changes. The equipment designed includes $3 / 4$ and $1-1 / 2$ in. diameter core end plugs and holders, and thick-walled pressure vessels for operation in the 2,000 to 6,000 psi range. 
During the next month, fabrication of the equipment will begin. A decision will be made on what type of high-pressure liquid pump is to be used and based upon that decision a pump will be ordered.

\subsection{Lawrence Livermore Laboratory}

Application of both theoretical models has indicated that the boundary conditions applied to the finite size continuum simulated with the codes can cause some problems. Several techniques have been assessed to reduce the effect of these boundaries. The most promising technique now being pursued is to enlarge the zonal sizes along the boundaries thereby extending the boundary without increasing grid size. This technique has been applied with other finite element codes for this same purpose.

The theoretical model which includes pore-pressure effects has been used to analyze the effect of changes in pore-pressure on the stress intensification factor. The fluid which is used to drive a hydraulic fracture can propagate into the surrounding reservoir material and thereby increase the pressure of the fluids near the fracture. The analysis indicates that the fracture stress intensification factor decreases as the pressure in the surrounding pore spaces increases. The stress intensification factor is believed to be a measure of the onset of fracture propagation from a stable or quasi-stable state.

LIL has continued to apply the other theoretical model to analyze the effects of layering near a hydrofracture on the surface deformations. Preliminary indications are that changes in the Young's modulus from layer to layer and changes in layer geometry can cause some change in the position of the maximum surface deflection or slope. The boundaries still cause some problems with the solutions, but "fixes" for these boundary problems and these modifications will be incorporated into both the models.

\subsubsection{Experimental Model}

The effects of interfaces on fracture characteristics have received much attention in the experimental effort this month. LLL has experimentally studied unbonded interfaces between limestone test specimens. For example, with a given surface roughness, a hydraulically driven fracture will not cross the unbonded interface when a normal compressive stress of $1,000 \mathrm{psi}$ is imposed across the interface. However, when the normal stress is increased to 1,500 psi, the hydraulic fractures propagate across the interface. Other experimental measurements were performed to determine the effect of the vertical stress on the hydraulic fracture orientation. Here a triaxial cell was applied which allowed imposition of a horizontal stress field which had a different value in 
each direction. Although not fully analyzed, the data indicates that for ratios of $\sigma_{\mathrm{v}} / \sigma_{\mathrm{Hmin}}$ smaller than one, the initial vertically created fractures turned and became horizontal. For a ratio greater than one, the fractures remained vertical.

\subsubsection{Geology and Geophysics}

During the last month the report discussing the available knowledge of the rock geometry and rock mechanics of the western tight gas sands was completed. The report is in editing and drafting prior to publishing.

\subsection{Sandia Laboratories}

4.3.1 Instrument Systems Development

\subsubsection{Surmont Project}

The Surmont Project was a hydrofracture experiment in the Athabasca Tar sands in northern Alberta, completed on October 1, 1977. The purpose of the experiment was to determine if it is possible to establish a reliable technique of creating horizontal fractures which will be in communication with wells drilled on commercial spacing. The project was jointly funded by the Alberta Oil Sands Technology and Research Authority (AOSTRA) and NUMAC Oil and Gas Ltd. with the Amoco Production Company acting as consultant. Amoco suggested that Sandia Laboratories and USGS participate by using the electrical and tilt fracture mapping techniques that are presently under investigation.

The fracture well was drilled to a depth of 1,170 ft and casing was run to 1,150 ft. Two fractures were created. The first, in the open, hole section, was an attempt to create a horizontal fracture at a tar sands-Devonian shale interface at approximately 1,160 ft. The second was through an abrasijet cut in the casing at 1,030 ft into the tar sand formation.

During the initial portion of the first fracture 480 BBL of gelled water were pumped. The AMOCO downhole TV camera was located in the open hole portion of the well 1 and surface potential and tilt measurements were made. Temperature logs were run on the well after this pumping and due to an unexpected temperature response in the well, the second portion of the fracture was delayed, while additional temperature logs were run. In the second pumping, 1,600 $\overline{\mathrm{B}} \overline{\mathrm{B}} \mathrm{L}$ of colored grout were used, and surface potential and tilt measurements were recorded.

Immediate post test analysis of the potential data failed to reveal any specific fracture orientation. 
Two evaluation wells have been drilled by NUMAC, $100 \mathrm{ft}$ to the northeast and $50 \mathrm{ft}$ to the southeast of the fractured well. Core samples from both wells failed to reveal any colored grout.

\subsubsection{NTS Seismic Data Analysis}

Analysis of the seismic signals generated from a fracture performed on August 23 was begun by examining the source locations determined from the $S$-wave and $P$-wave difference times received at three locations with known velocities. High speed (160 in. per second) Visicorder playback records were made of 36 signals. Of these signals the P-wave and $S$-wave arrival times were read for 20 signals. These records are unfiltered analog data. Digitizing and filtering would permit arrival times to be obtained for more signals. Two of the twenty signals produced erroneous answers because of poor resolutions in reading arrival times. For the other eighteen signals source locations were calculated from each set of three geophones; thus four locations are obtained for each signal. The average of these calculated locations is plotted in Figures 4-1 and 4-2. Figure $4-1$ is a plot with the. calculated locations projected on a horizontal plane. Figure 4-2 is a plot with the calculated locations projected on a vertical plane through the fracture.

\subsubsection{Mineback Stimulation Test Program}

Two hydraulic fractures have been completed in Hole 6 for an experiment to examine fracture behavior at a geologic formation interface. The first frac was performed on August 23, in an ash fall tuff interval beneath a welded tuff/ash fall tuff interface. The pipe became stuck in the hole and an extensive fishing operation and relogging of the hole was required. The second frac was performed on October 20 in the middle of the most dense interval of the welded tuff formation, about $30 \mathrm{ft}$ above the first frac interval.

After fishing operations were completed, total depth (TD) was tagged at 1,368 ft and caliper, velocity, electric and temperature logs were run. The hole was backfilled to $1,331 \mathrm{ft}$ with pea gravel. Figure 4-3 shows a Lynes packer was run in the hole on 2-7/8 in. tubing positioned at 1,324.5 ft and set at 1,500 psi.

On October 20, the shear pin was knocked out of the packer. A HewlettPackard (HP) quartz crystal oscillator pressure transducer and an Amerada pressure bomb were lowered downhole and positioned at 1,300 ft. The bottom hole pressure (BHP) was monitored as the hole was filled with water. After fill up, the BHP remained stable at 562.7 psi indicating that there was no fluid loss to the formation through the packed-off interval.

Breakdown commenced shortly afterwards, but as the BHP neared 1,400 psi, a leak in the lubricator at the wellhead forced a shutdown. The BHP 


\section{$\oplus \quad \oplus$}

GEOPHONE

LOCATION

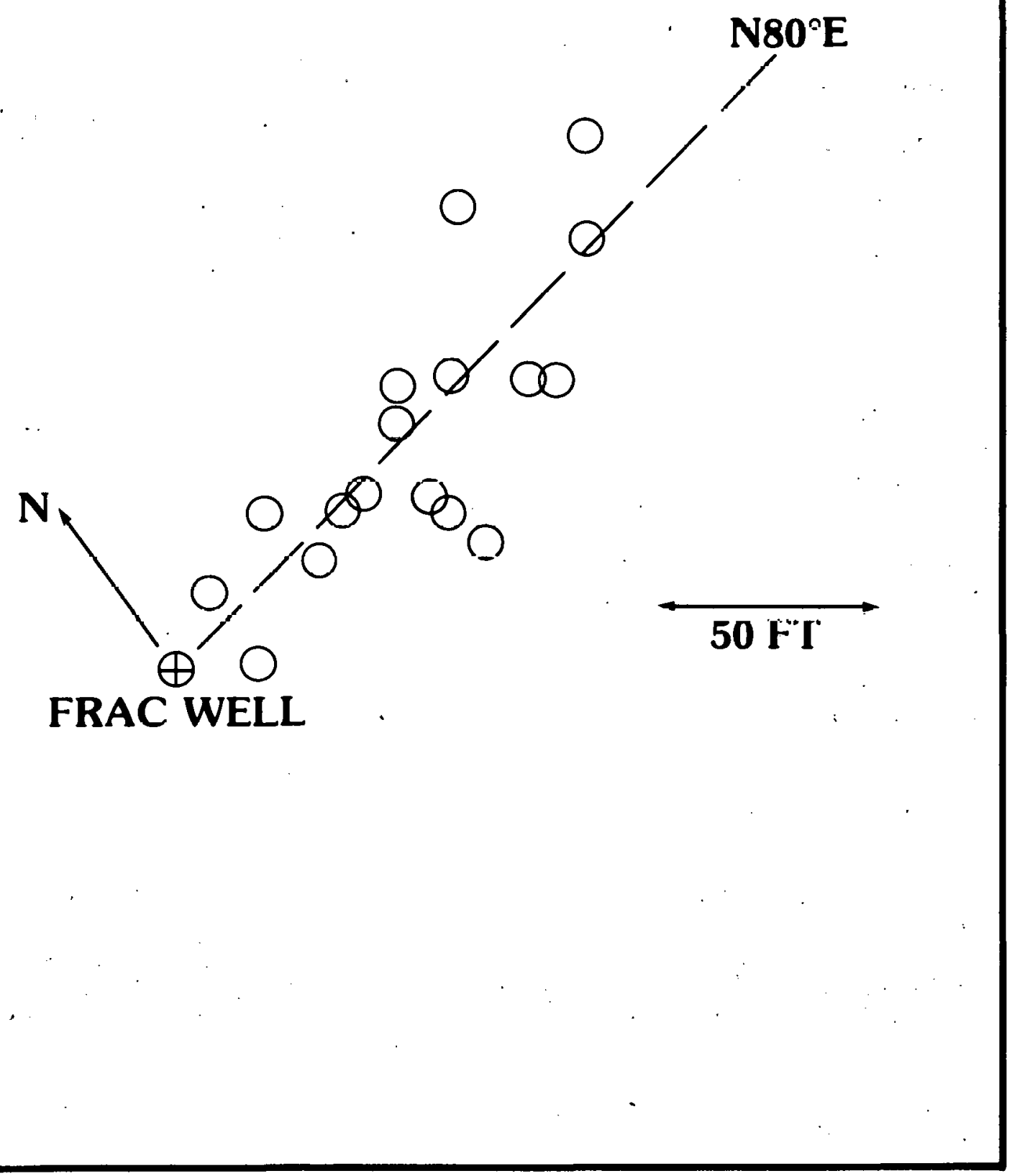

FIGURE 4-1 SEISMIC SOURCE LOCATIONS PROJECTED ON HORIZONTAL PLANE 


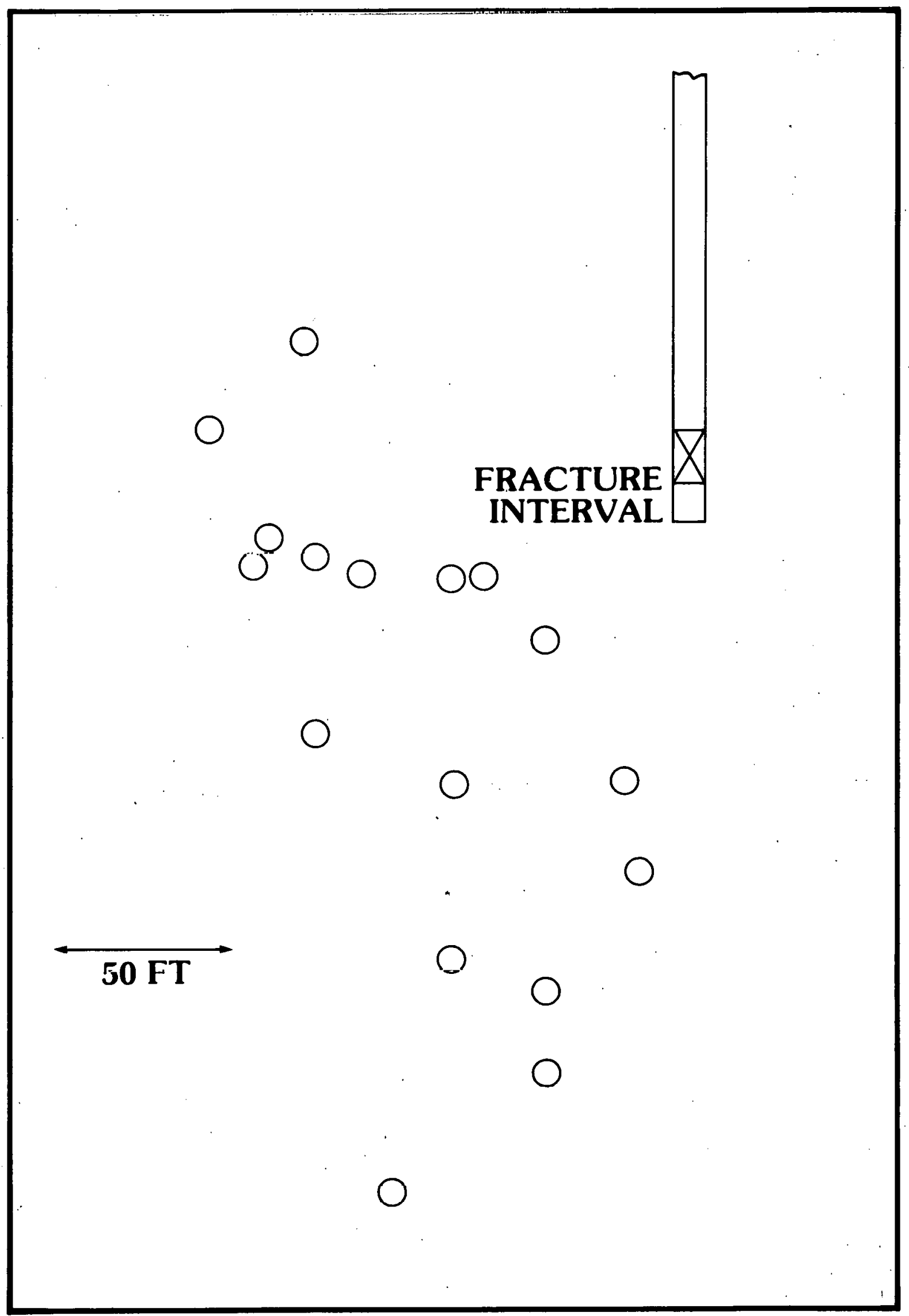

FIGURE 4-2 SEISMIC SOURCE LOCATIONS PROJECTED ON PLANE $\mathrm{N} 80^{\circ} \mathrm{E}$ 


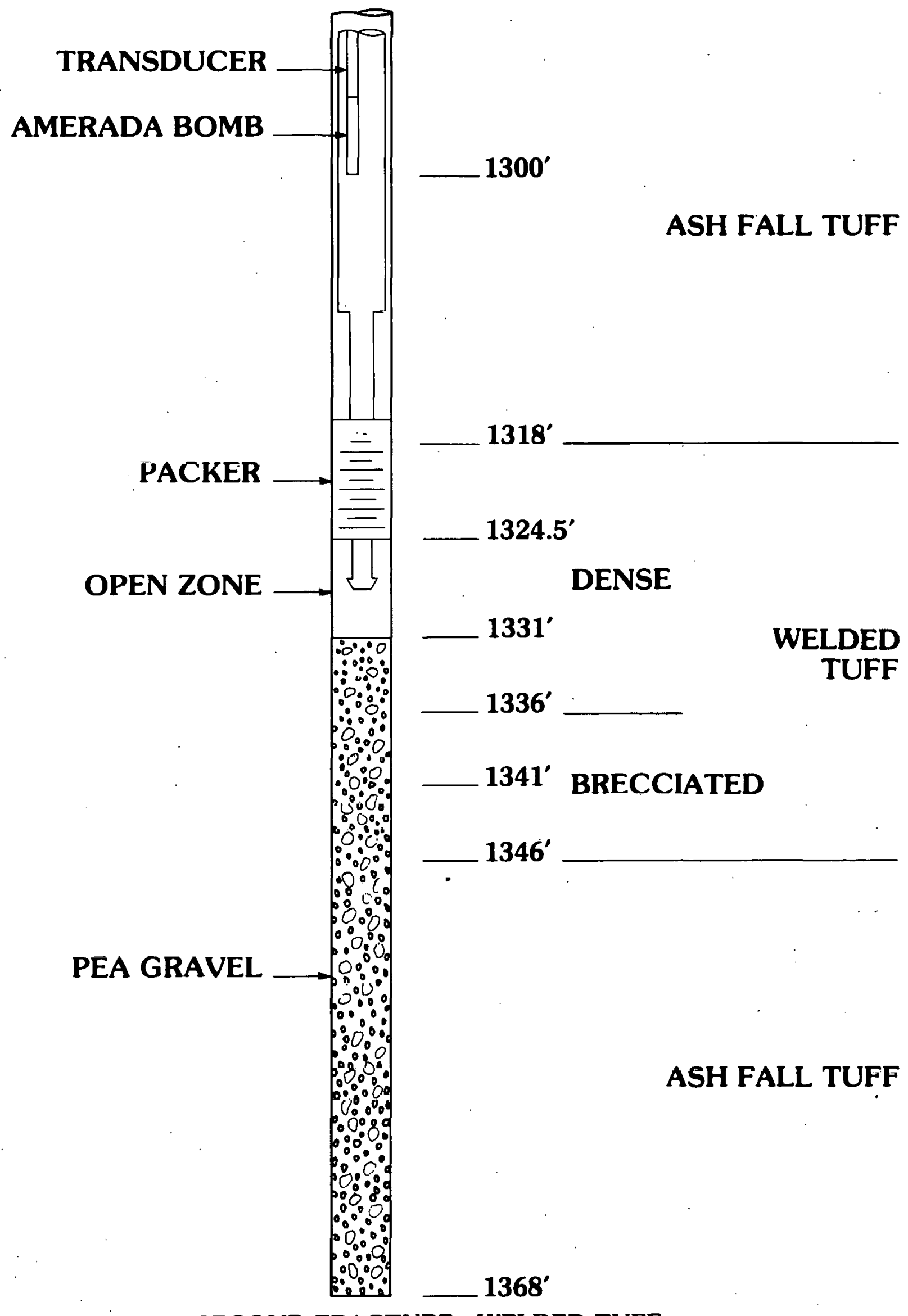

FIGURE 4-3 SECOND FRACTURE-WELDED TUFF 
dropped to 560 psi and remained constant. When pumping resumed, a pressure spike of 960 psi was observed followed by a pressure of 700 psi. A total of $30 \mathrm{BBL}$ of water were subsequently injected into the formation. The flow rate and wellhead pressure were recorded, and acoustic signals intercepted by geophones located in the formation. The well was shut in for $1 / 2$ hour for further acoustic measurements.

After quiet time was terminated and the instrumentation reset, Dowell began pumping 5,000 gal of blue grout into the formation at 6 BPM. This pumping was interrupted once, due to lubricator leakage, and the operation was shut down. After 117 BBL Dowell displaced the grout in the wellbore with l.O BBL of water and the well was shut in for a quiet period.

Figure 4-4 shows the pressure data obtained from the HP pressure transducer for the water breakdown and slurry injection. At times, the sensor behaved erratically due to a faulty cable connection and is indicated by "No Signal." It is not evident whether breakdown occurred at $1220 \mathrm{hrs}$ before the leak or at $1235 \mathrm{hrs}$. During injection, the pressure appeared to rlse falriy constantly (except for the shutdown) from $600 \mathrm{psi}$ to $700 \mathrm{psi}$. The instantaneous shut-in pressure is about 470 psi.

Figure 4-5 is a representation of the preliminary pressure results from the Amerada bomb for the initial fill up, water breakdown and slurry injection. Essentially, the information from the Amerada bomb is the same as that from the HP transducer. Reduced data from the Amerada bomb, wellhead pressure and flow rate have not yet been obtained.

Correlated pressure, flow rate and acoustic data will be essential information in the characterization of the fracturing process. Together with material property and in situ stress measurements obtained during mineback, this data should provide new insight into the interaction between a fracture and a geologic interface. Mineback to the experiment area is continuing and at the end of october, the tunnel face was 250 ft from Hole 6.

\subsubsection{Mobile Well Test Facility}

The fabrication and installation of components on the mast truck has been completed and the truck is presently in the paint shop. Expected completion date is in December, 1977.

Assembly of components continues for the instrument trailer. Expected completion date by Gearhart Owen Industries of Fort Worth, Texas is February 1, 1978.

No further logging and instrumentation systems equipment has been received during the reporting period. 


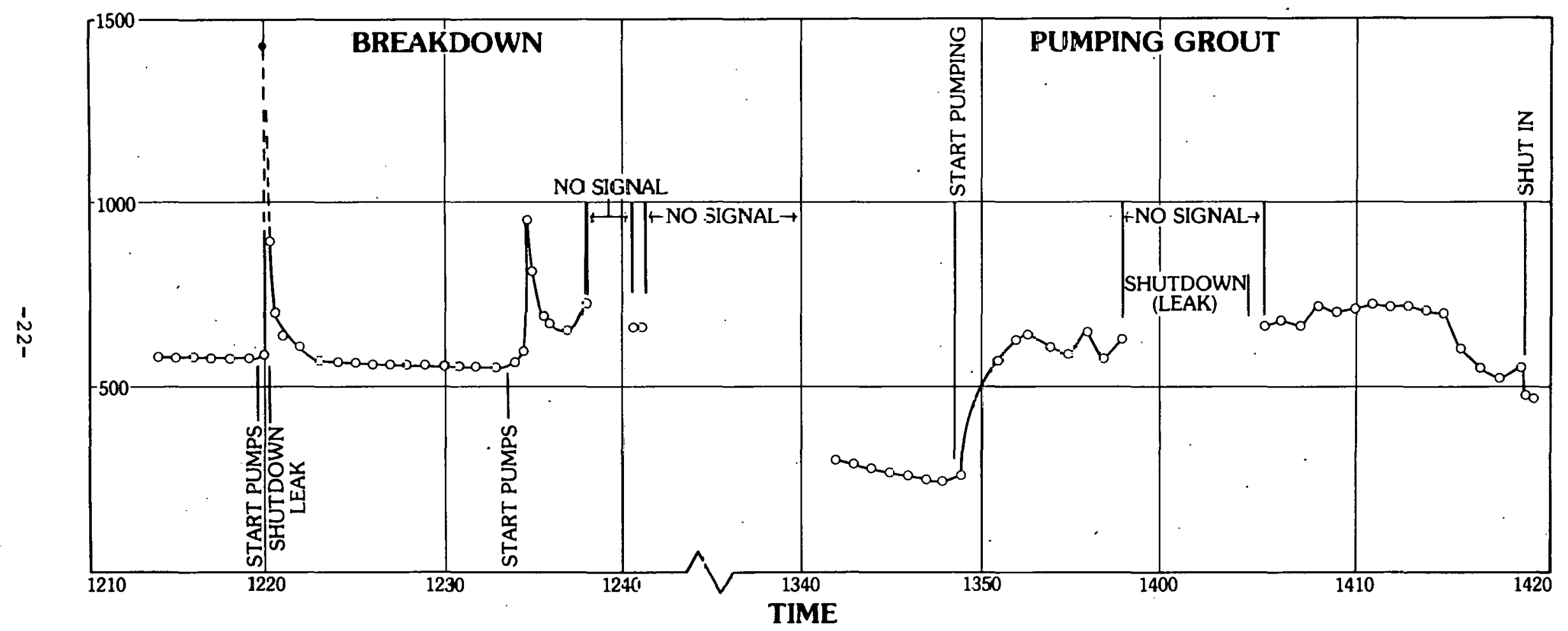

FIGURE 4-4 PRESSURE RECORD-HP TRANSDUCER 


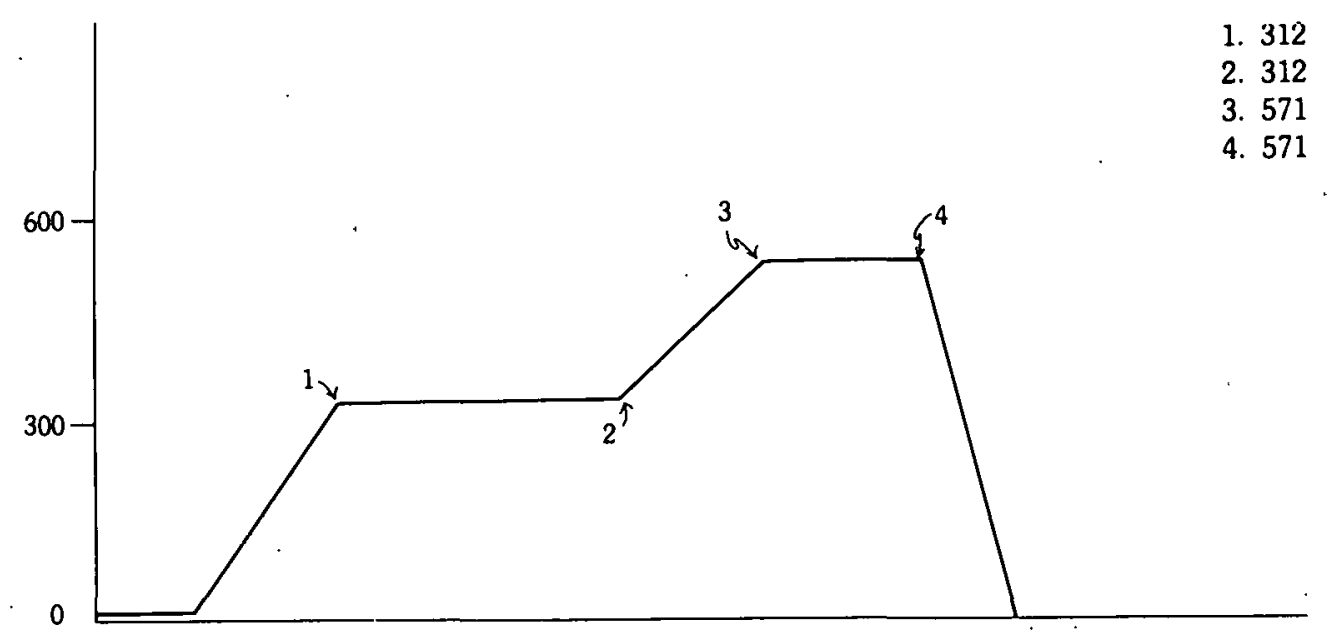

INITIAL FILL UP WITH WATER

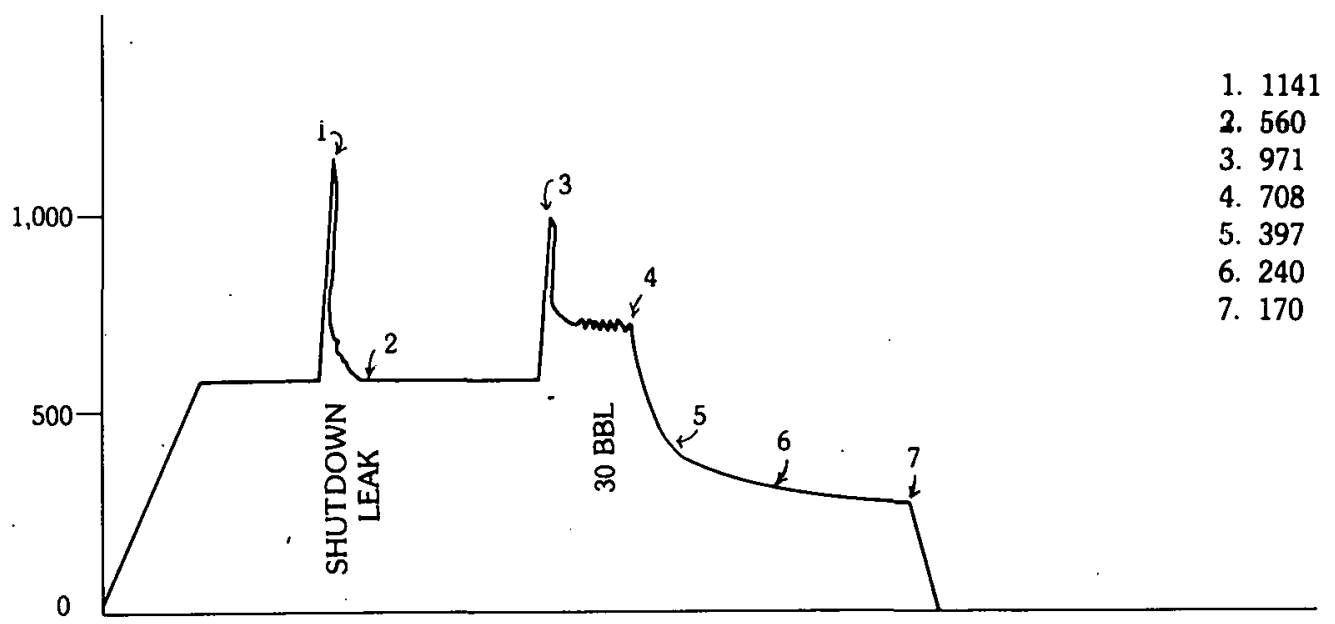

WATER BREAKDOWN

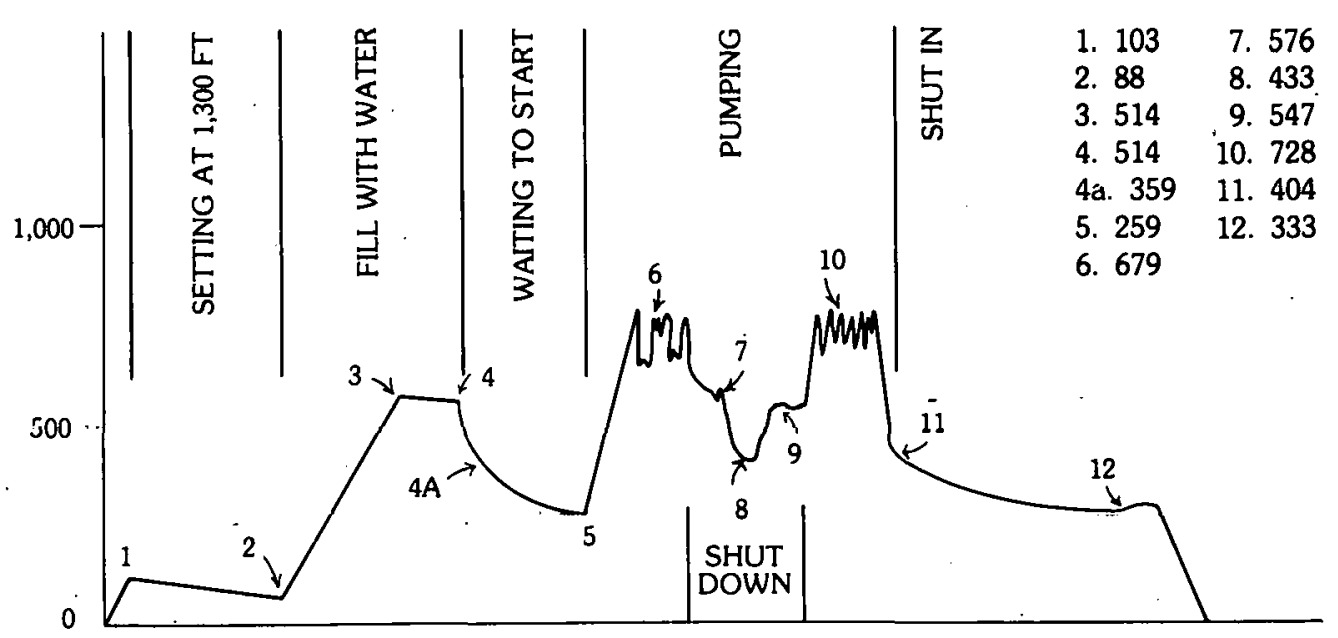

FIGURE 4-5 PRELIMINARY FIELD PRESSURE RESULTS-AMERDA BOMB 


\subsubsection{Other Activities}

Representatives of Shell Oil Company visited Sandia on October 6, 1977. The purpose of the meeting was to review Sandia activities in the Instrumentation Development and Mineback Test projects and to explore areas for further cooperation and interaction. Alex B. Crawley, Division of Oil, Gas and In Situ Technology, Department of Energy, also attended.

Two papers--"Results from a MHF Surface Electrical Potential Mapping Experiment," by Carl L. Schuster and Leo J.- Keck and "In Situ Examination of Hydraulic Fractures," by L.D. Tyler, W.C. Vollendorf, and D.A. Northrop were presented by Schuster, Tyler and Northrop at the First Eastern Gas Shales Symposium, Morgantown, West Virgin1a, october 17 - 19, 1977. The papers appeared in a preprint volume and will be published in the proceedings.

\subsection{U.S. Geological Survey (USGS) Borehole Gravity Meter}

The new borehole gravity meter is still at the contractor's laboratory. USGS has installed the sensor and is now installing the newly USGS designed heater control and leveling equipment.

\subsection{U.S. Geological Survey/Menlo Park-Tiltmeter}

Experiments are presently being conducted at the Laramie Energy Research Center test site, near Rock Springs, Wyoming. Results have been very favorable, even during the inclement weather. It is expected that the wyoming tests will be completed by mid-December. Field testing will then be started on the sandstone experiments in Colorado, scheduled for completion by mid-February.

Three reports by M.D. Wood and N.E. King to be published to the open file are presently in draft form. These are:

\footnotetext{
"Interpretation of Tilt Yonjtoring Experiments Associated with Massive Hydraulic Fracturing of Devonian Shale near Iluntington, Wcot Virginia"

"Intorprotation of Tilt Mnnitnring Fixperiments Associated with Massive Hydraulic Fracturing of the Muddy J Sandstone of Wattenberg, Colorado"

"Interpretation of Tilt Monitoring Experiments Associated with Hydraulic Fracturing of Green River Shale, Rock Springs, Wyoming"
} 


\section{FIELD TESTS AND DEMONSTRATIONS}

\subsection{Background}

There are three active MHF tests in the Uinta Basin in Utah and the Piceance Basin in Colorado. These are experiments in the Upper Cretaceous tight gas sand formations. The organizations involved are:

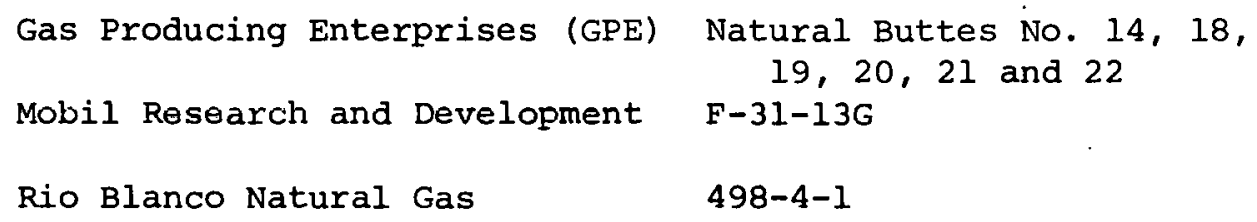

The CER Corporation MHF 3 is on inactive status pending satisfactory contractual arrangements to perform additional tests, and for final disposition of the well.

Colorado Interstate Gas Company has been awarded a contract to determine if productivity in low permeability reservoirs. can be improved by reducing the interstitial, water saturation. They are using two wells, the Sprague No. 1 and Miller No. 1, completed in the Dakota J Formation in the Wattenberg Field in north central Colorado.

The following sections summarize the progress of active projects. 
TABLE 5-1 MHF CONTRACT LOCATIONS AND FRAC DATA

\begin{tabular}{|c|c|c|c|c|c|c|}
\hline $\begin{array}{l}\text { COMPANY, BASIN } \\
\text { AND FORMATION }\end{array}$ & LOCATION & WELL & FRACTURED & $\begin{array}{l}\text { FRAC. } \\
\text { DATE }\end{array}$ & $\begin{array}{c}\text { FRAC } \\
\text { TREATMENT } \\
\end{array}$ & $\begin{array}{c}\text { FLUID } \\
\text { INJECTED }\end{array}$ \\
\hline & T / R / Se:c & & Feet & & Lbs. of Sand & $10^{3}$ Gal. \\
\hline $\begin{array}{l}\text { AUSTRAL } \\
\text { Piceance, } \\
\text { Mesaverde }\end{array}$ & $\begin{array}{l}\text { 7S, 94W, S3 } \\
\text { Garfield Co. } \\
\text { Colorado }\end{array}$ & $\begin{array}{c}\text { Federal } \\
3.94\end{array}$ & $5,170-6,333$ & $8-25-76$ & $1,140,000$ & $\begin{array}{l}542 \\
\text { gel } \mathrm{H}_{2} 0\end{array}$ \\
\hline $\begin{array}{l}\text { CER CORPORATION } \\
\text { Piceance, } \\
\text { Mesaverde }\end{array}$ & $\begin{array}{l}3 \mathrm{~S}, 98 \mathrm{~W}, \mathrm{~S} 11 \\
\text { Rio Blanco Co. } \\
\text { Colorado }\end{array}$ & RB-MHF-3 & $\begin{array}{l}8,048-8,078 \\
7,760-7,864 \\
5,925-6,016 \\
5,851-5,869\end{array}$ & $\begin{array}{r}10-23-74 \\
5-2-75 \\
5-4-76 \\
11-3-76\end{array}$ & $\begin{array}{l}400,000 \\
880,000 \\
815,000 \\
448,000\end{array}$ & $\begin{array}{l}117 \mathrm{Gel} \\
285 \mathrm{Gel} \\
400 \mathrm{Gel} \\
228 \mathrm{Gel}\end{array}$ \\
\hline \multirow[t]{4}{*}{$\begin{array}{l}\text { GAS PRODUCING } \\
\text { ENTERPRISES, INC. } \\
\text { Uinta, } \\
\text { Wasatch and } \\
\text { Mesaverde }\end{array}$} & $\begin{array}{l}\text { 10S, 22E: S10 } \\
\text { Uintah County } \\
\text { Utah } \\
\\
10 S, 21 E . S 21 \\
\text { Uintah County } \\
\text { Utah }\end{array}$ & $\begin{array}{l}\text { National } \\
\text { Buttes } \\
\text { No. } 18 \\
\text { National } \\
\text { Buttes } \\
\text { No. } 19\end{array}$ & $\begin{array}{l}6,490-8,952 \\
7,224-9,664\end{array}$ & $\begin{array}{l}9-21-76 \\
9-28-76\end{array}$ & $1,480,000$ & $745 \mathrm{Gel}$ \\
\hline & $\begin{array}{l}\text { 9S, 21E, S22 } \\
\text { Uintah Coumty } \\
\text { Utah }\end{array}$ & $\begin{array}{l}\text { National } \\
\text { Buttes } \\
\text { No. } 14\end{array}$ & $6,646-8,004$ & $3-15-77$ & $1,093,000$ & $544 \mathrm{Gel}$ \\
\hline & $\begin{array}{l}\text { 9S, 21E, S23 } \\
\text { Uintah County } \\
\text { Utah }\end{array}$ & $\begin{array}{l}\text { National } \\
\text { Buttes } \\
\text { No. } 20\end{array}$ & $8,498 \cdot 9,476$ & $6-22-77$ & 826,000 & $322 \mathrm{Gel}$ \\
\hline & $\begin{array}{l}\text { 10S, 22E, S21 } \\
\text { Uintah County } \\
\text { Utah }\end{array}$ & $\begin{array}{l}\text { CIGE } \\
\text { No. } 21\end{array}$ & NB & icheduled & & \\
\hline
\end{tabular}




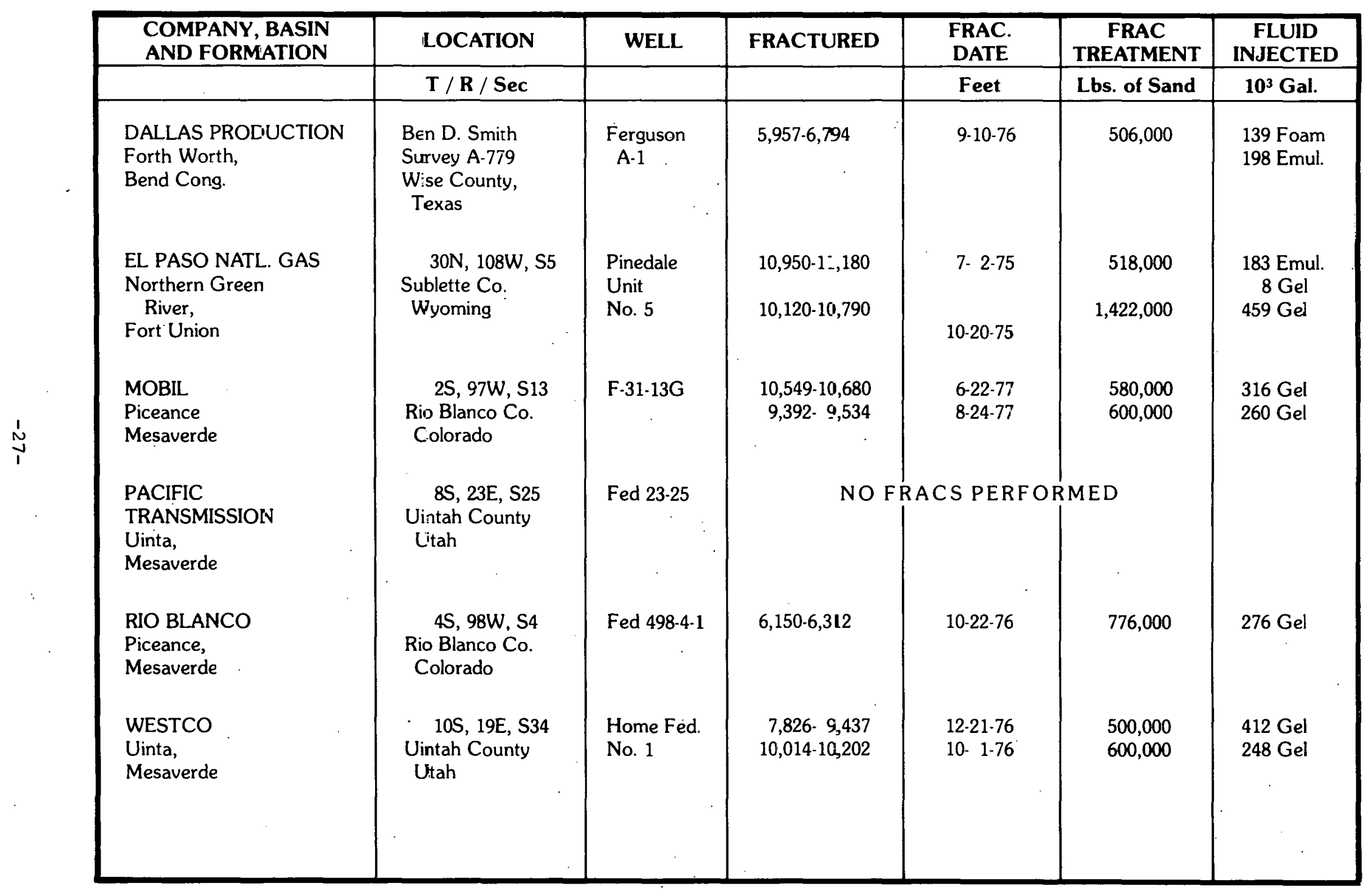




\section{FRACTURING EXPERIMENT}

CER Geonuclear Corp.

Las Vegas, Nevada

Interagency Agreement Date:

Project Cost (estimaled).

Principal Investigator:

Technical Advisor for DOE:
Status: Awaiting Advisory

Committee Decision

June 19,1974

DOE $\ldots \ldots \ldots \ldots \ldots \ldots \ldots \ldots \ldots \ldots 1,975,0 n n$

Industry $\ldots \ldots \ldots \ldots \ldots \ldots \ldots, 1,630,000$

Total ................. \$3,475,000

G. R. Leutkehans

Charles H. Atkinson, Bartlesville Energy

Research Center

\section{OBJECTIVE}

This stimulation experiment is being conducted in low-permeahility, massive gasbearing sandstone reservoirs in the Piceance Basin in western Colorado, to test advanced hydraulic fracturing technology where it has not been possible to obtain commercial production rates. This test is located about 1 mile from the 1973 Rio Blanco nuclear stimulation site to permit comparison of nuclear and hydraulic fracturing techniques in this area.
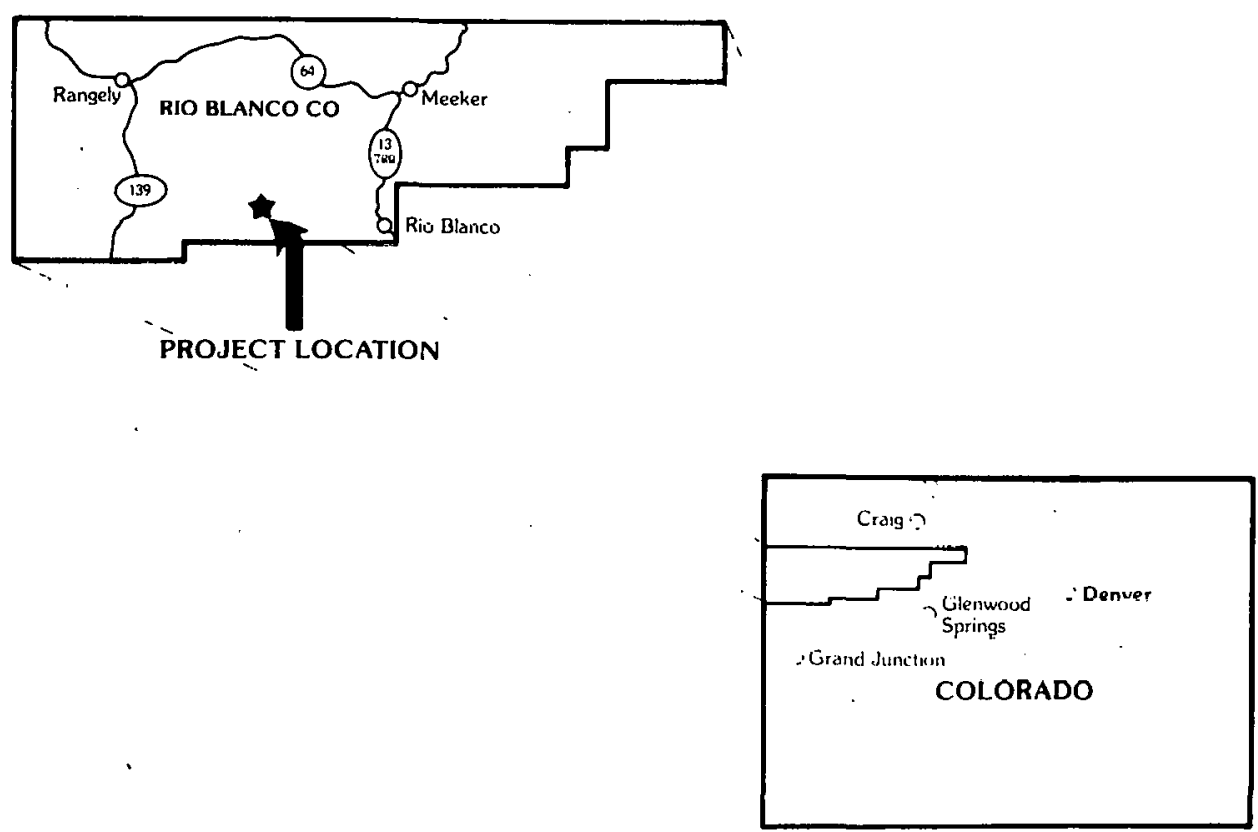


\subsection{CER Corporation}

\subsubsection{Scope of Work}

DOE Contract EY-76-C-08-0623 was signed with CER Corporation in March, 1974. The Rio Blanco Massive Hydráulic Fracturing Project was fielded in 1974 as a joint Industry/DOE demonstration to test the relative formations that were stimulated by the Rio Blanco Nuclear fracturing experiment. The project is essentially a companion effort to and a continuation of the preceding nuclear stimulation project, which took place in May, 1973.

The Rio Blanco projects are located in the northern part of the Piceance Basin of northwestern Colorado, one of a number of basins in the western United States that have substantial quantities of natural gas locked in tight sand reservoirs.

\subsubsection{Current status}

Field activities on the MHF 3 well have been curtailed. Further action is dependant upon satisfactory contractual arrangements with an outside party to complete the comingling of the fractured gas zones and perform some additional testing in return for the well and subsequent gas production. 
Colorado Interstate Gas Company Colorado Springs, Colorado
Status: Activity to Commence January 1, 1978

Total Project Cost:

DOE .

$\$ 75,000$

CIG.

Total

Howard Fredrickson 99,000

Principal Investigator:

Technical Project Officer for DOE:

. H. Atkinson, Bartlesville Energy

Research Center

\section{OBJECTIVE}

Cyclic injection of dry natural gas is the method to be used to increase produc. tivity of tight gas sands.
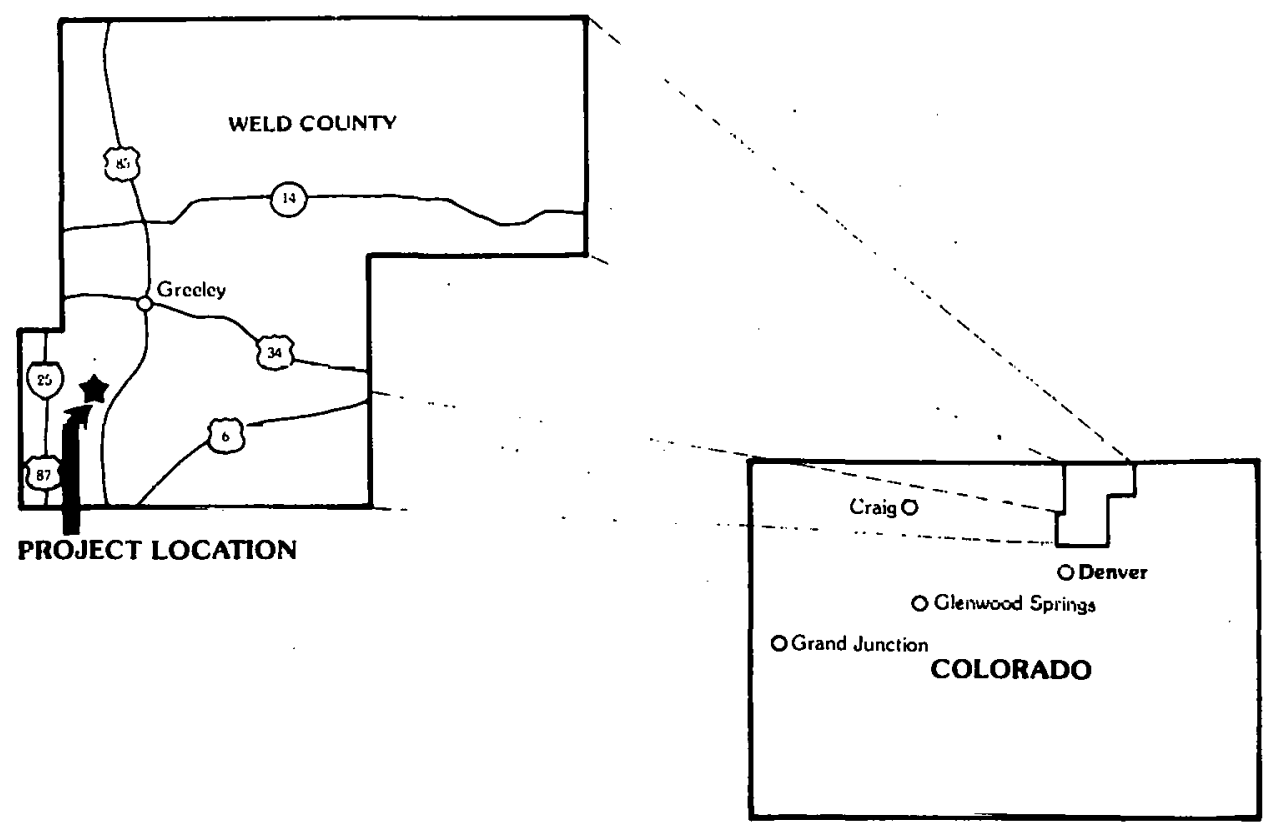


\subsection{Colorado Interstate Gas Company}

\subsubsection{Scope of Work}

On September I, 1977, Contract No. EY-77-C-08-1514 was entered into between DOE and Colorado Interstate Gas Company in the amount of $\$ 75,000$. The contractor will fund the program in the amount of $\$ 99,000+$.

The Colorado Interstate Gas Company will attempt to determine if the productivity of wells completed in low permeability natural gas reservoirs can be improved by reducing the interstitial water saturation. The method used to accomplish this reduction of water saturation will be a cyclic injection of dry natural gas. In addition, cyclic injection of dry natural gas may improve the productivity through dehydration of matrix clays and the removal of formation damage adjacent to the surfaces of induced fracture.

\subsubsection{Current Status}

Preliminary design of the facilities is underway by CIG's engineering department and specifications of necessary equipment, such as the compressor and dehydrator, have been developed in preparation for bid solicitation. Field activities on this project, presently scheduled to commence on January 1, 1978, will begin with the installation of equipment. During February and March, the initial bottom hole pressure buildup will be conducted. Cyclic injection and withdrawal will be performed during the second and third quarters and during october and November, the 60 day pressure buildup will be conducted. The evaluation and report will be made during December, 1978. 
NATURAL BUTTES UNIT, UINTAH COUNTY,

UTAH MASSIVE HYDRAULIC FRACTURING

DEMONSTRATION

EY-76-C-08-0681

Gas Producing Enterprises, Inc.

Status: Active

Subsidiary of Coastal States Gas Co.

Houston, Texas

Contract Date:

Anticipated Completion:

Total Project Cost:

Principal Investigator:

July 1, 1976

Sept. 30, 1978

DOE

$\$ 2,827,000$

Industry (prior costs) . . . . . . . $1,881,000$

Industry (new costs) $\ldots \ldots \ldots \ldots \ldots, 3,051,000$

Total

$\$ 7,759,000$

Technical Project Officer:

W. E. Spencer

C. H. Atkinson, Bartlesville Energy

Research Center

\section{OBJECTIVE}

To evaluate the effectiveness of massive hydraulic fracturing for stimulating natural gas production from thick, deep sandstone reservoirs having low permeability:

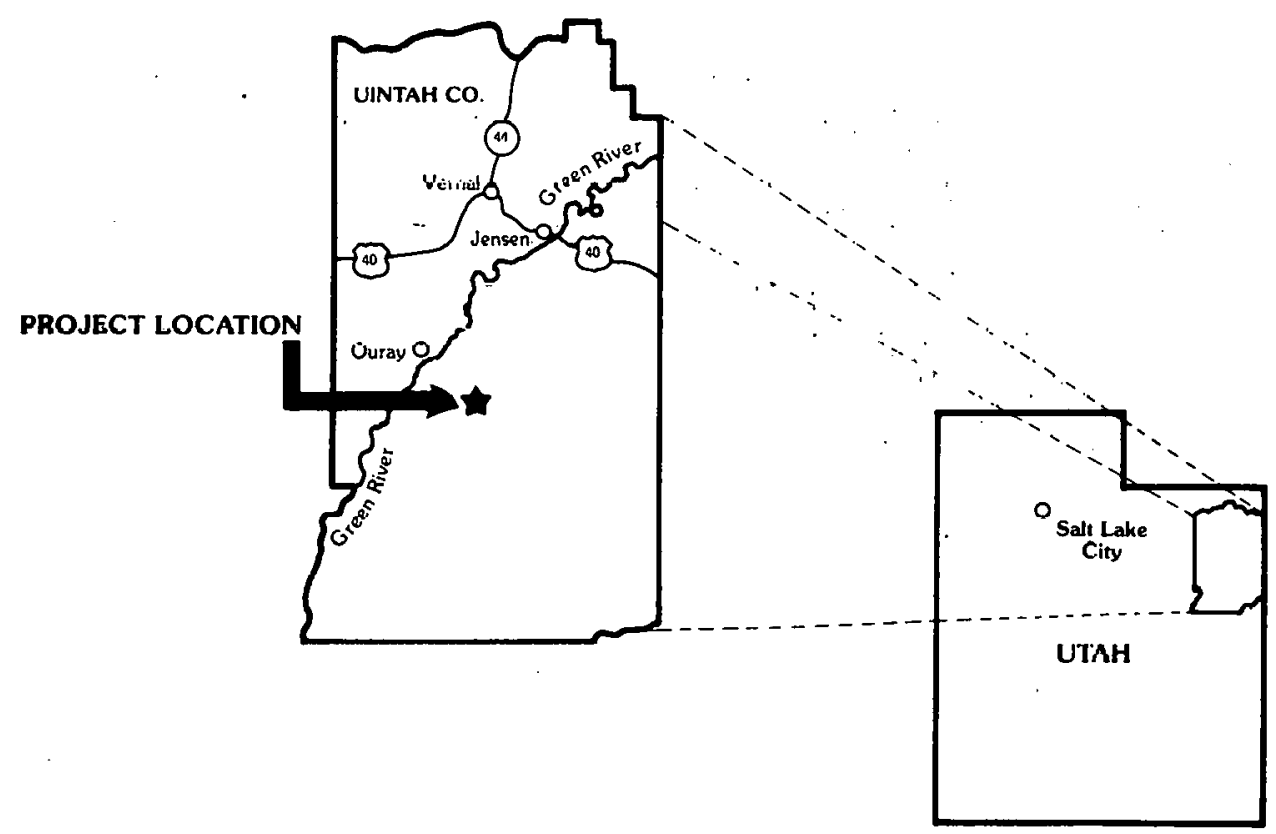




\title{
5.4 Gas Producing Enterprises Inc.
}

\author{
5.4.1 Scope of Work
}

On July 1, 1976, a Contract, EY-76-C-08-0681, was entered into between DOE and Gas Producing Enterprises Inc. concerning the conduct of a MHF experimental program. The GPE program was greater in scope compared to the other MHF contracting companies. Originally, two old wells; Natural Buttes 18 and 14, and four new wells; 1, 20, 21 and 22 were to be fractured. Variations between wells were to consist of amounts of frac fluid, sand size, porosity of zone tested and fluid design. A contract modification for Phase $V$ of the MHF Demonstration Contract provides for an add-on to the Natural Buttes No. 21 (tentative new designation is CIGE No. 21) for coring, running of extra logs, and to run production and buildup tests on individual sand members within two sections of the Mesaverde. The core data, including special interpretation, and production test data will be correlated. In addition, there will be an attempt to obtain post MHF performance of these individual sand members for better prediction of potential productivity of a sand member by electric log interpretation alone.

The contract modification provides for DOE contribution of an extra $\$ 672,000$ with GPE contributing roughly $\$ 100,000$.

\subsubsection{Current Status}

Natural Buttes No. $18,19,14$ and 20 are still on production. Natural Buttes No. 22 has been drilled to $8,622 \mathrm{ft}$ and $4-1 / 2$ in. $\mathrm{N}-80,13-1 / 2$ $1 \mathrm{~b} / \mathrm{ft} 8 \mathrm{rd} \mathrm{R}-3$ casing run and set at 8,622 ft. PBTD is 8,605 ft. TDT and CBL logs were run and perfs selected. The MHF treatment design was approved by DOE and the preliminary work completed. On November 21 , 1977, the MHF experiment was conducted.

Natural Buttes No. 9 has been cleaned out to 8,959 PBTD and tubing and packer run and set at $6,492 \mathrm{ft}$. The $M H F$ is being redesigned to allow treatment to be pumped down the tubing only. Thie decign is oompleted and the project is waiting on bids for the redesigned MHF treatment.

Natural Buttes 21 is now drilled and cased. The well was extensively cored and log suites were run by two service companies. The well is now awaiting the cased hole logging program which will commence the middle of December.

The Schlumberger open hole log suite consists of a Dual Laterolog, Microspherically Focused Log, Gammay Ray, Compensated Neutron Log, Formation Density Log, Caliper, Borehole Compensated Sonic Log, High Resolution Dipmeter, Fracture Identification Log, and experimental Long Spaced Sonic. All logs were taped and will be computer processed into a Saraband Sandstone Analysis and Mechanical Properties Log. The 
experimental Long Spaced Sonic consisted of four different transmitterreceiver spacings and recorded on tape the entire wave train as received. These can be combined into both a compressional and a shear wave, $\Delta t$. In addition, Schlumberger plans to construct a special mechanical properties log using the shear wave data.

The Dresser Atlas open hole log suite includes Dual Laterolog, Microlaterolog, Compensated Densilog, Compensated Neutron, Caliper, Gamma Ray, Bore Hole Compensated Acoustilog, Spectralog, Dual Detector Neutron Lifetime Log, Four-Arm Diplog, and Frac-Log.

The cased hole logging program will consist of dual spacing Thermal Neutron Decay-Time Log, Cement Bond/Variable Density Log, experimental Long Spaced Sonic, Dual Detector Neutron Lifetime Log, Compensated Neutron Log, Gamma Ray, and collar locator.

Table 5-2 correlates logging depths to core depths and summarizes the quality of cored section. Twenty-one percent of the $551 \mathrm{ft}$ of recovered core is interpreted from the $\log$ as being invaded zones of greater than eight percent porosity. Most of the quality sands in the cored interval will be selected for production tests at the completion of the cased hole logging program.

The logs will be analyzed in detail. The scope of this work will include the relation of log parameters in shaly sands to the in situ simulated Terra Tek core analysis. Production tests in selected zones will also be interrelated to the $\log$ and core analysis. Shaly sand water saturation equations used by private industry will be scrutinized and compared in their applicability to Uinta Basin Wasatch and Mesaverde results oriented log analysis. The Natural Buttes 21 study will be interpreted with other DOE wells in the Uinta Basin hopefully to derive a statistically valid empirical relationship between log parameters and water saturation in the wasatch and Mesaverde.

In addition, the data will be manipulated by various cross-plot techniques and computer programs in an attempt to better relate the log data to productive zones.

Table 5-3 is a description of cores recovered from the Natural Buttes No. 21 well. 
TABLE 5-2 COMPARISON OF CORE INTERVALS TO LOG INTERPRETED POROSITY ZONES NATURAL BUTTES 21

\begin{tabular}{|c|c|c|c|c|c|}
\hline Core No. & $\begin{array}{l}\text { Cored Interval } \\
\text { (Drillers Depth) }\end{array}$ & $\begin{array}{c}\text { Core Interval } \\
\text { Recovered } \\
\text { (Drillers Depth) }\end{array}$ & $\begin{array}{c}\text { Log Correlation } \\
\text { to Core Recovery } \\
\text { (SWS Drillers Depth) }\end{array}$ & $\begin{array}{l}\begin{array}{l}\text { Core Recovered } \\
\text { (Feet) }\end{array} \\
\end{array}$ & $\begin{array}{c}\text { Filtrate Invaded Sands } \\
\text { Having Porosities } \\
\text { (Feet) } \\
\end{array}$ \\
\hline 1 & $4,389 \cdot 4,452$ & $4,389-4,443$ & $4,389-4,443$ & 54 & 12 \\
\hline 2 & $4,452-4,508$ & $4,452 \cdot 4,508$ & $4,451-4,507$ & 56 & 12 \\
\hline 3 & $6,350-6,383$ & $6,350 \cdot 6,383$ & $6,345-6,378$ & 33 & 0 \\
\hline 4 & $6,383 \cdot 6,414$ & $6,383 \cdot 6,409$ & $6,378 \cdot 6,404$ & 26 & 0 \\
\hline 5 & $6,414 \cdot 6,452$ & $6,414 \cdot 6,449$ & $6,408-6,443$ & 35 & 0 \\
\hline 6 & $6,452-6,479$ & $6,452 \cdot 6,477$ & $6,446 \cdot 6,471$ & 25 & 6 \\
\hline 7 & $6,479 \cdot 6,509$ & $6,479 \cdot 6,509$ & $6,473 \cdot 6,504$ & 31 & 14 \\
\hline 8 & $\pi, 400-7,453$ & $7,400 \cdot 7,443$ & $7,397 \cdot 7,440$ & 43 & 0 \\
\hline 9 & $7,453-7,496$ & $7,453-7,496$ & $7,446-7,489$ & 43 & 0 \\
\hline 10 & $\pi, 496 \cdot 7,556$ & $7,496 \cdot 7,556$ & $7,489 \cdot 7,549$ & 60 & 0 \\
\hline 11 & $8,422 \cdot 8,435$ & $8,422 \cdot 8,435$ & $8,408-8,422$ & 14 & 0 \\
\hline 12 & $8,435 \cdot 8,466$ & $8,435 \cdot 8,466$ & $8,422-8,453$ & 31 & 26 \\
\hline 13 & $8,466 \cdot 8,507$ & $8,466 \cdot 8,507$ & $8,453 \cdot 8,495$ & 42 & 22 \\
\hline 14 & $8,507 \cdot 8,565$ & $8,507 \cdot 8,565$ & $8,495 \cdot 8,553$ & 58 & 24 \\
\hline & & . & TOTALS & 551 & 116 \\
\hline
\end{tabular}


TABLE 5-3

\section{DEPTH INTERVAL}

\section{Core \#1: 4389' - $4451^{\prime}$}

Recovered 54'

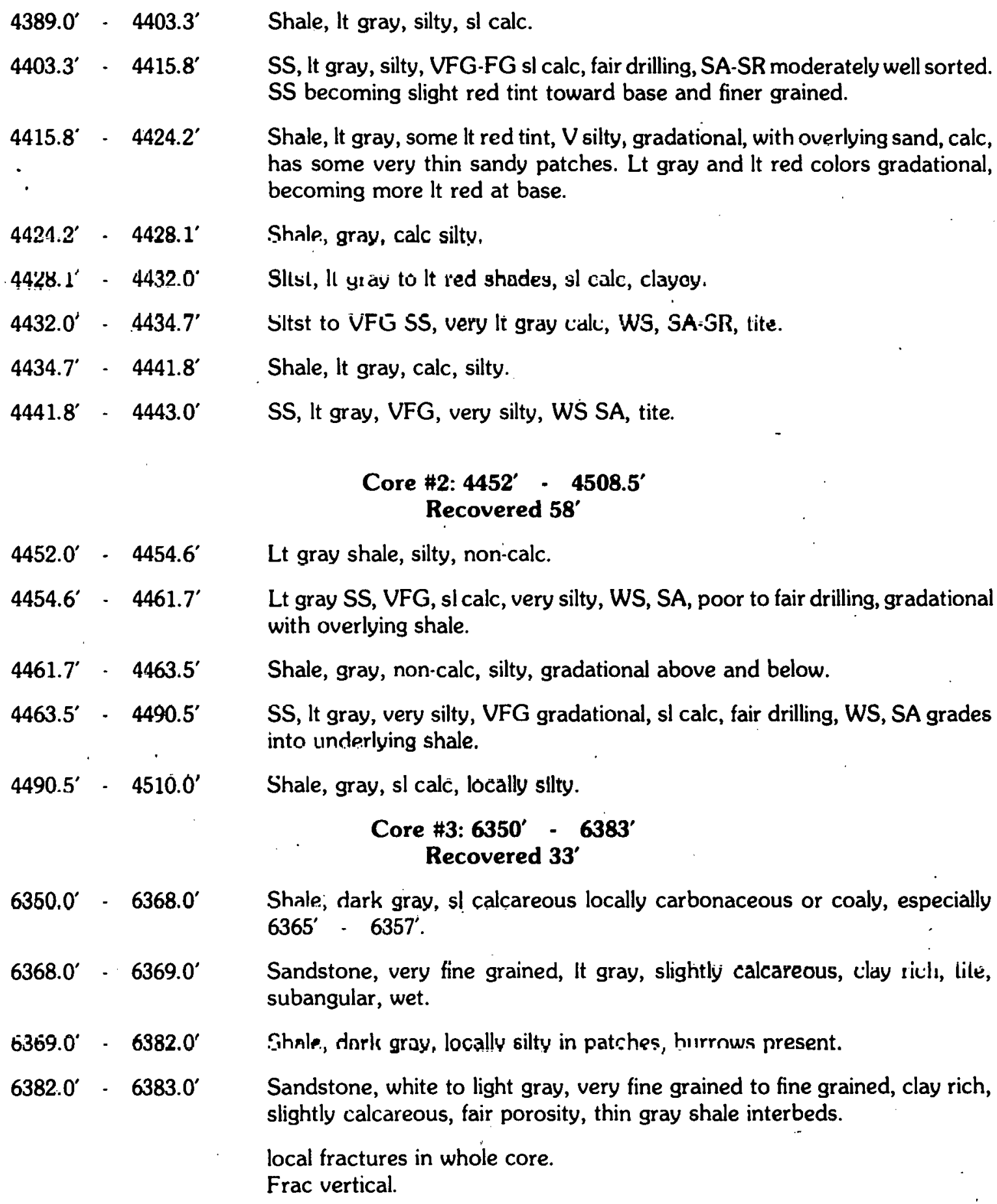


No coring time breaks, gas units 200 to 360 with no significant shows. No conn. gas. 2' flare while coring. 3100 to 68000 ppm gas.

MW 9.4 to 9.6 \# during coring.

\title{
Core \#4: $6382.8^{\prime}-6413.6^{\prime}$ Recovered 26.0' (Bbl. jammed)
}

$6382.8^{\prime} \quad 6383.5^{\prime} \quad$ Ss, very fine grained, white to light gray, slightly calcareous, poor porosity, tite.

$6383.5^{\prime}$ - 6405.7 Shale, medium to dark gray, coaly locally.

$6405.7^{\prime}$ - 6408.2 $\quad$ Ss, very fine grained, white to light gray, slightly calcareous, poor porosity, clay filled locally, coaly locally and bedded, burrows.

$6408.2^{\prime} \quad 6408.8^{\prime} \quad$ Siltstone, grading into red above.

Sperry orient. Equipment failed.

\section{Core \#5: 6413.6' - 6452.4 \\ Recovered 35.3'}

\begin{abstract}
6413.6' - 6414.7' Siltstone, light gray, locally sandy.
$6414.7^{\prime}$ - 6423.3' Shale, medium to dark gray, coaly, slightly calcareous.

$6423.3^{\prime}-6425.5^{\circ}$ Sandstone, very fine grained to siltstone, light gray, slightly calcareous', hard and tite, poor porosity.

$6425.5^{\prime}$ - $6448.9^{\prime} \quad$ Shale, medium to dark gray, very silty to locally sandy, locally very coaly, horizontal fractures and burrowed.
\end{abstract}

No core time breaks - BGG gas units varied from 40 to 280 units.

\section{Core \#6: 6452.4' - 6478. $7^{\prime}$ \\ Recovered 24.7'}

\begin{abstract}
$6452.4^{\prime}$ - 6460.2' Shale, light to dark gray, very silty, locally slightly calcareous, locally coaly, some burrows.

$6460.2^{\prime}$ - 6461.1' Sandstone, very fine grained, white to light gray, silty, well sorted, poor to fair porosity, locally thin shaly intervals, some clay fill, tite.

$6461.1^{\prime}$ - 6470.6 Shale, light gray, very silty, grading to overlying sandstone, slightly calcareous, burrowed.

$6470.6^{\circ}$ - 6477.1' Sandstone, very fine grained to fine grained, well sorted, light gray, fair porosity, fair perm., very little clay fill, slightly calcareous, some horizontal fractures and burrows. Much fine grained at base where tite. (This was best sand in this overall interval) (Also slight gas increase 400 to 480 to 280 in interval).
\end{abstract}


DEPTH INTERVAL

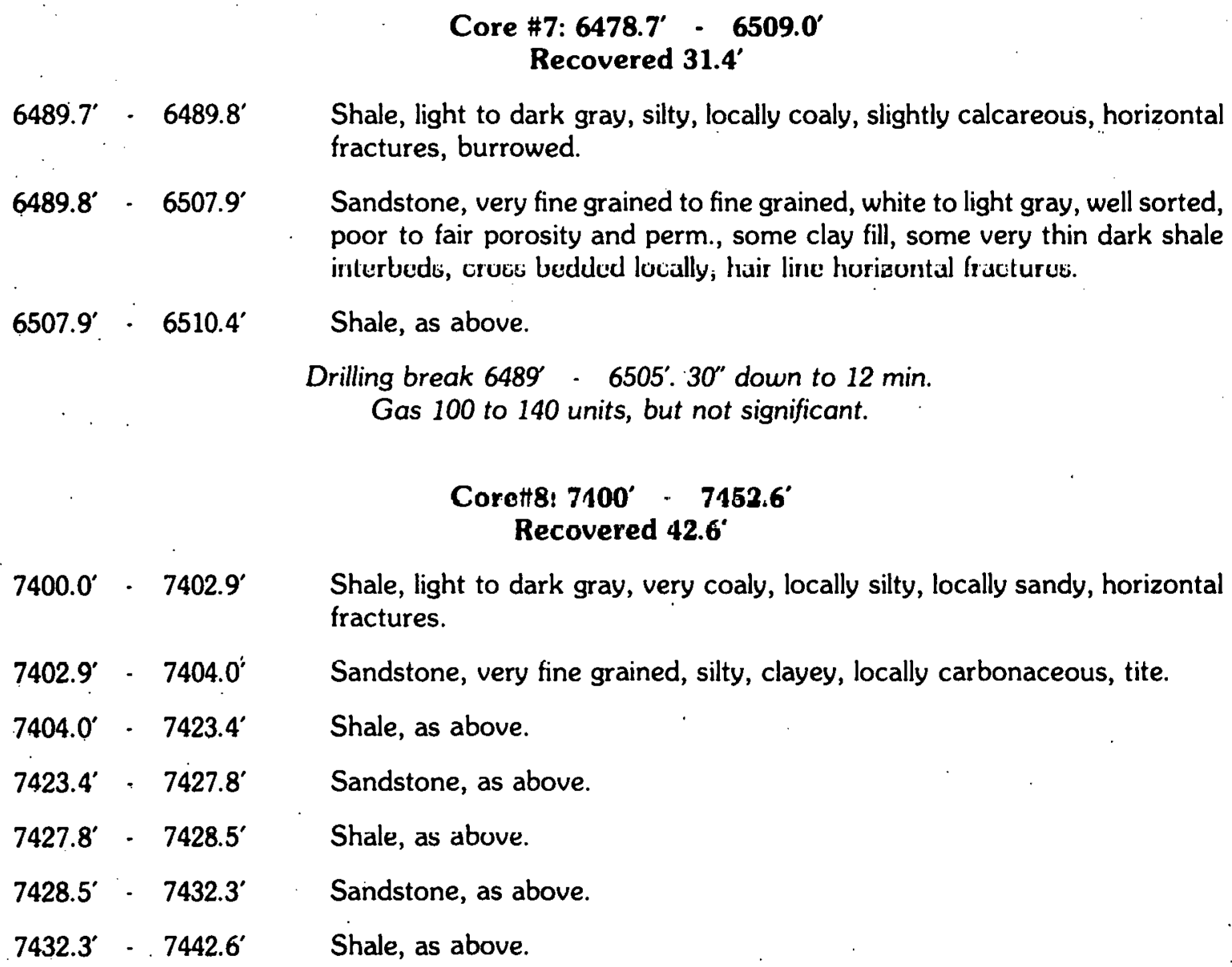

$6489.7^{\prime} \cdot 6489.8^{\prime}$

$6489.8^{\circ}-6507.9^{\prime}$

$6507.9^{\prime} \cdot 6510.4^{\prime}$

Shale, as above.

Drilling break $6489^{\prime}$ - $6505^{\prime}$. 30" down to $12 \mathrm{~min}$.

Gas 100 to 140 units, but not significant.

\section{Corett8! 7100' - 7452.6' \\ Recovered $42.6^{\circ}$}

$7400.0^{\prime} \cdot 7402.9^{\prime}$

$7402.9^{\prime}-7404.0^{\prime}$

$7404.0^{\prime}$ - 7423.4'

$7423.4^{\prime}=7427.8^{\prime}$

$7427.8^{\prime}-7428.5^{\prime}$

$7428.5^{\circ}$ - $7432.3^{\prime}$

$7432.3^{\prime}-.7442 .6^{\prime}$

Shale, light to dark gray, silty, locally coaly, slightly calcareous, horizontal fractures, burrowed.

Sandstone, very fine grained to fine grained, white to light gray, well sorted, poor to fair porosity and perm., some clay fill, some very thin dark shale interbeds, croes bedded locally, hair line horizuntal fractures.

Shale, light to dark gray, very coaly, locally silty, locally sandy, horizontal fractures.

Sandstone, very fine grained, silty, clayey, locally carbonaceous, tite.

Shale, as above.

Sandstone, as above.

Shale, as above.

Sandstone, as above.

Shale, as above.

$7452.6^{\circ} \cdot 7469.7^{\circ}$

$7469.7^{\prime}-7471.4^{\prime}$

$7471.4^{\prime}-7473.4^{\prime}$

$7473.4^{\prime}$ - $7477.0^{\prime}$

$7477.0^{\circ}$ - 7480.7'

$7480.7^{\circ}-7483.0^{\prime}$

$7483.0^{\circ}-7495.9^{\prime}$
Total, $9^{\prime}$ sandstone.

\section{Conre \#9. 7452.6' - $74959^{\prime}$}

Recovered 43.3'.

Shale, coarse, medium to light gray, silty, coaly, locally sandy.

Sandstone, white to light gray, very fine grained, silty, coaly, tite.

Shale, as above.

Sandstone, as above, very shaley, locally coaly.

Shale, as above.

Sandstone, as above.

Shale, as above.

Total 7 sandstone. 
DEPTH INTERVAL

\section{CORE DESCRIPTION}

\section{Core\# 10: 7495.9' - 7555.0'}

\section{Recovered 60.6'}

$7495.9^{\prime} \cdot 7529.7^{\prime}$

Shale, medium to dark gray, very coaly, silty, locally sandy, few horizontal fractures.

$7529.7^{\prime}$ - $7530.7^{\prime} \quad$ Sandstone, very fine grained, light gray, very silty, tite.

$7530.7^{\prime} \cdot 7556.5^{\prime} \quad$ Shale, as above.

*Taken directly from coring information issued by Gas Producing Enterprises. 


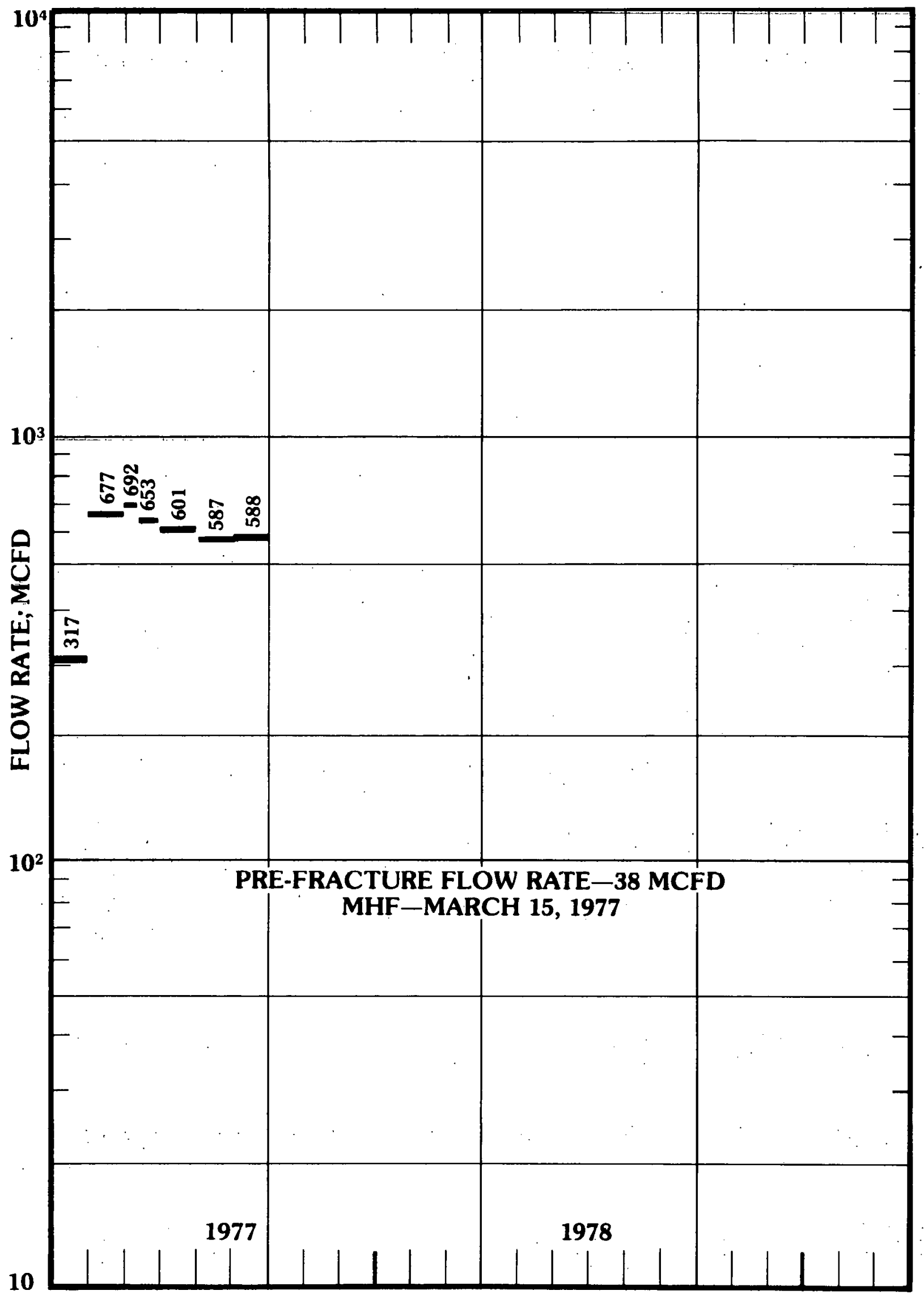

FIGURE 5-1 FLOW RATE PERFORMANCE OF NATURAL BUTTES NO. 14 WELL 


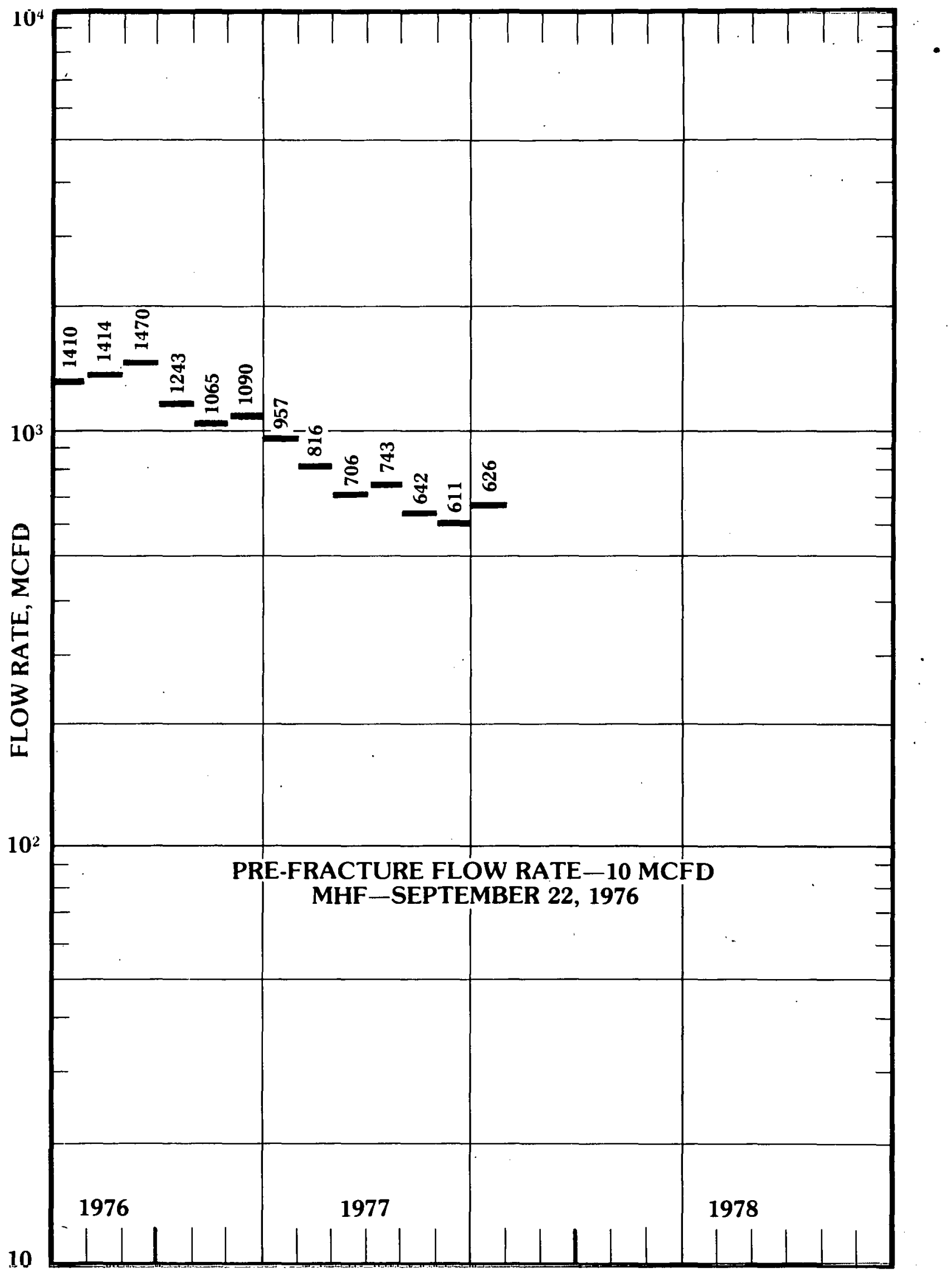

FIGURE 5-2 FLOW RATE PERFORMANCE OF NATURAL BUTTES NO. 18 WELL 


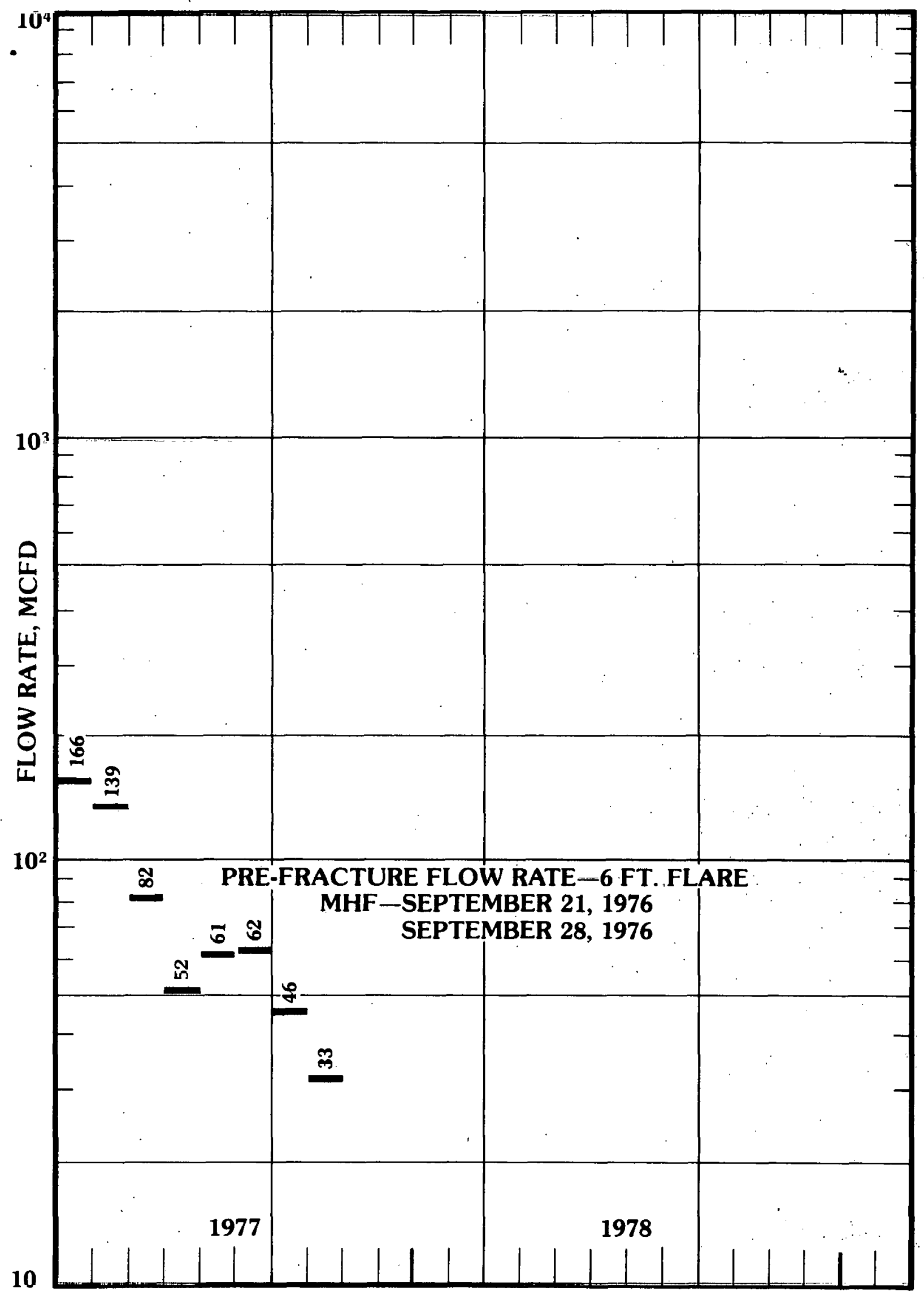

FIGURE 5-3 FLOW RATE PERFORMANCE OF NATURAL BUTTES NO. 19 WELL 


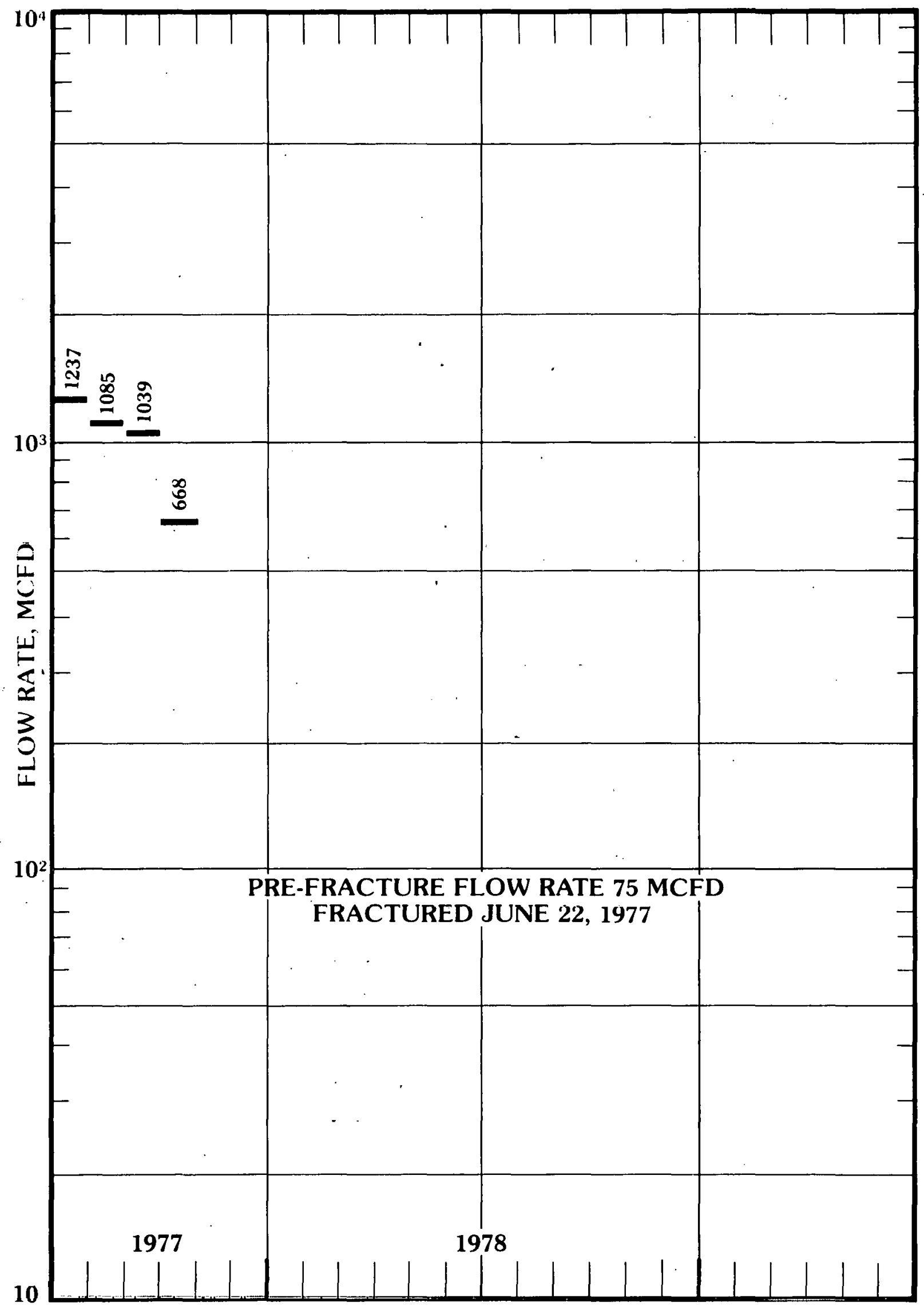

FIGURE 5-4 FLOW RATE PERFORMANCE OF NATURAL BUTTES NO. 20 WELL 
Mobil Research and Development Corporation

Status: Active

Dallas, Texas

Contract Date:

Anticipated Completion:

Total Project Cost:

Prineipal investigutur:

Technical Project Officer:
July 1, 1976

December 31, 1978

DOE ..................... \$2,600,000

Contractor (prior costs) . . . . . . . 2,376,485

Contractor (new costs) . . . . . . . 1,590,515

Total ...................... \$6,567,000

John L. Fitch

C. H. Atkinson, Bartlesuille Energy

Research Center

\section{OBJECTIVE}

To evaluate the effectiveness of massive hydraulic fracturing for stimulating natural gas production from thick, deep sandstone reservoirs having extremely low permeability.

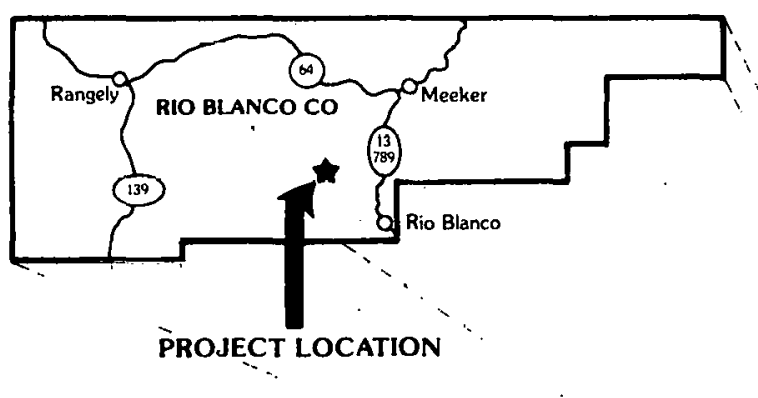




\subsection{Mobil Research and Development Corporation}

\subsubsection{Scope of Work}

Mobil was awarded DOE Contract EY-76-C-08-0678, along with Signal Drilling for the amount of $\$ 2.6$ million for a MHF experiment in Rio Blanco County, Colorado. The scope of work under the contract is to be performed in three phases involving a well to be drilled in the Piceance Creek gas field, Rio Blanco County, Colorado.

\subsubsection{Current status}

Previously, the F-31-13G well had two sands within the gross interval between 9,392 - 9,538 ft, perforated, broken down, tested and flowed to the pit. The measured flow rate was 930 MCFD declining to 700 MCFD in three days when the well was shut in for pressure buildup. A second flow test was then performed and the data obtained is tabulated below.

\begin{tabular}{cccc}
$\begin{array}{c}\text { Date } \\
\text { October }\end{array}$ & $\begin{array}{c}\text { Gas Rate } \\
\text { MCFD }\end{array}$ & $\begin{array}{c}\text { Water Rate } \\
\text { BPD }\end{array}$ & $\begin{array}{c}\text { Cond. Rate } \\
\text { BPD }\end{array}$ \\
\hline 12 & 1,900 & 48 & 10 \\
13 & 1,850 & 116 & 5 \\
14 & 1,700 & 105 & 19 \\
$15-16$ & --- & --- & -- \\
17 & 1,513 & 85 & 23
\end{tabular}

During the flow test, noise-temperature logs were run which showed the greatest amount of gas entry i.n the 9,392 - 9,432 ft interval.

Following these tests, the well was killed with $\mathrm{KCl}$ water and the retrievable bridge plug was moved from 9,600 ft to 9,370 ft. Preparations were then made to perforate and test the 9,254 - 9,320 ft interval.

The well was swabbed down to $3,000 \mathrm{ft}$ and perforated with 33 jet shots using a 4 in. O.D., centralized, hollow carrier gun. The perfs were broken down with $\mathrm{KCl}$ water at $12.5 \mathrm{BPM}$. Good ball action was observed, as ball-off occurred with approximately 50 balls at the perfs. Initial instantaneous shut in pressure (ISIP) was 925 psi; final ISIP was 1,000 psi. The well was immediately opened to flow and after about 4 hours the rate was about 400 MCFD. Additional flow data are tabulated as follows : 


\begin{tabular}{cccc}
$\begin{array}{c}\text { Date } \\
\text { October }\end{array}$ & $\begin{array}{c}\text { Gas Rate } \\
\text { MCFD }\end{array}$ & $\begin{array}{c}\text { Water Rate } \\
\text { SPD }\end{array}$ & $\begin{array}{c}\text { Cond. Rate } \\
\text { BPD }\end{array}$ \\
\hline 20 & 250 & $290+$ & --- \\
21 & 155 & 22 & 2 \\
22 & 125 & -- & --
\end{tabular}

Noise-temperature logs run during the flow period showed most of the gas coming from the lower part of the perforated interval.

The well was shut in for buildup on October 22. Some difficulty was experienced with the Hewlett-Packard (HP), surface recording, quartz pressure gauge. However, sufficient readings were obtained with the HP quage, a bottom hole Kuster gauge and surface readings to provide a well defined pressure buildup curve. The $\mathrm{kh}$ of the interval is about $0.07 \mathrm{md}-\mathrm{ft}$.

As of November 14, the sand at 9,086 - 9,125 ft had been perforated, broken down and tested. During the test, the maximum flow rate observed was 400 MCFD, 5 hours after the breakdown on November 7 . The flow rate on November 8 was 185 MCFD; and on November 9, 158 MCFD. Pressure buildup data show the kh to be about $0.05 \mathrm{md}-\mathrm{ft}$.

It is planned to clean the well out to total depth, flow it to the sales line during the winter and resume testing in April, 1978.

Flow surveys and noise-temperature logs will be run prior to perforating additional zones.

The following graphs show the pressure buildup data for the specified zones. The raw data are not included, but are available. 


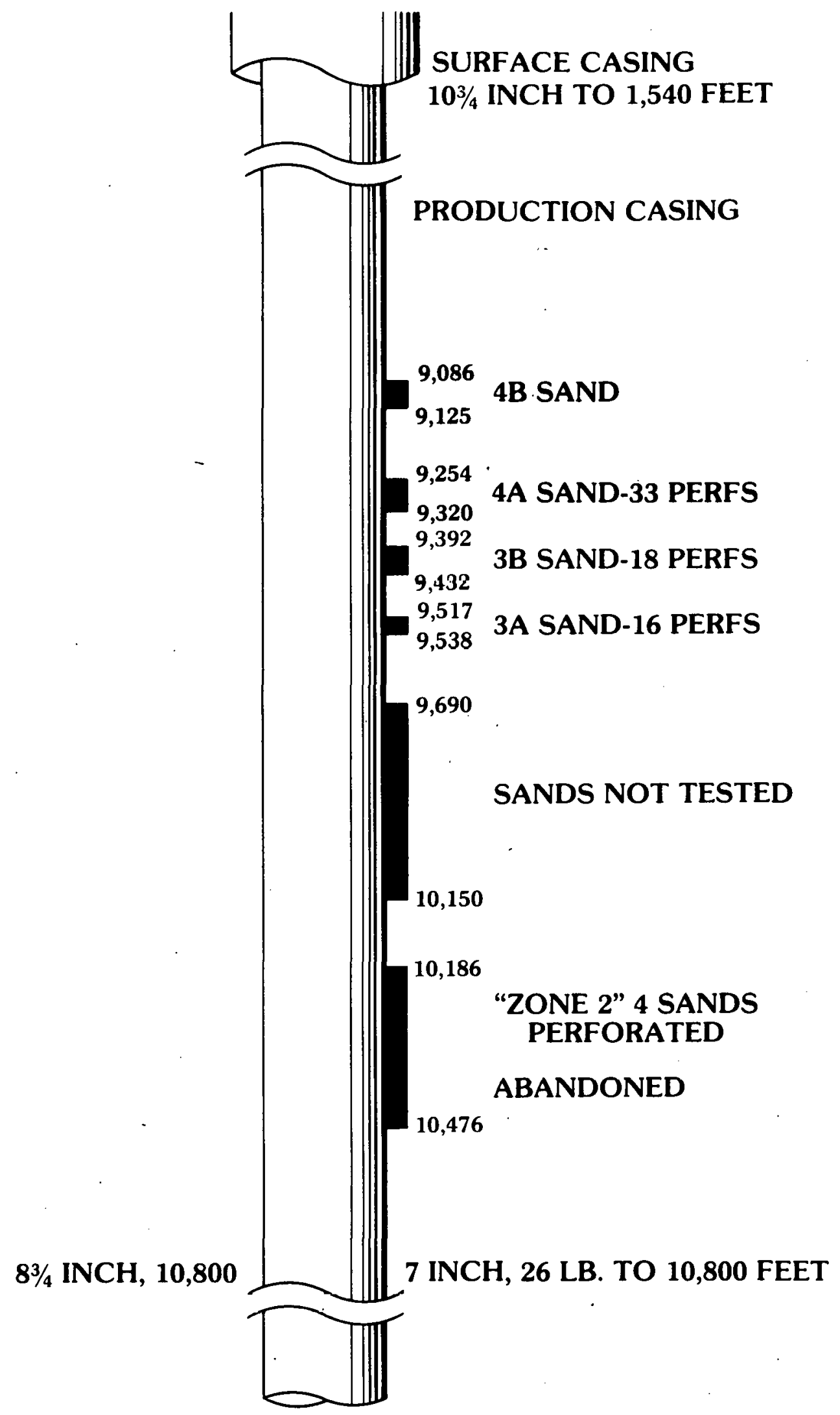

FIGURE 5-5 SCHEMATIC OF MOBIL F-31-13G WELL SHOWING 3A AND $3 B$ LONES 


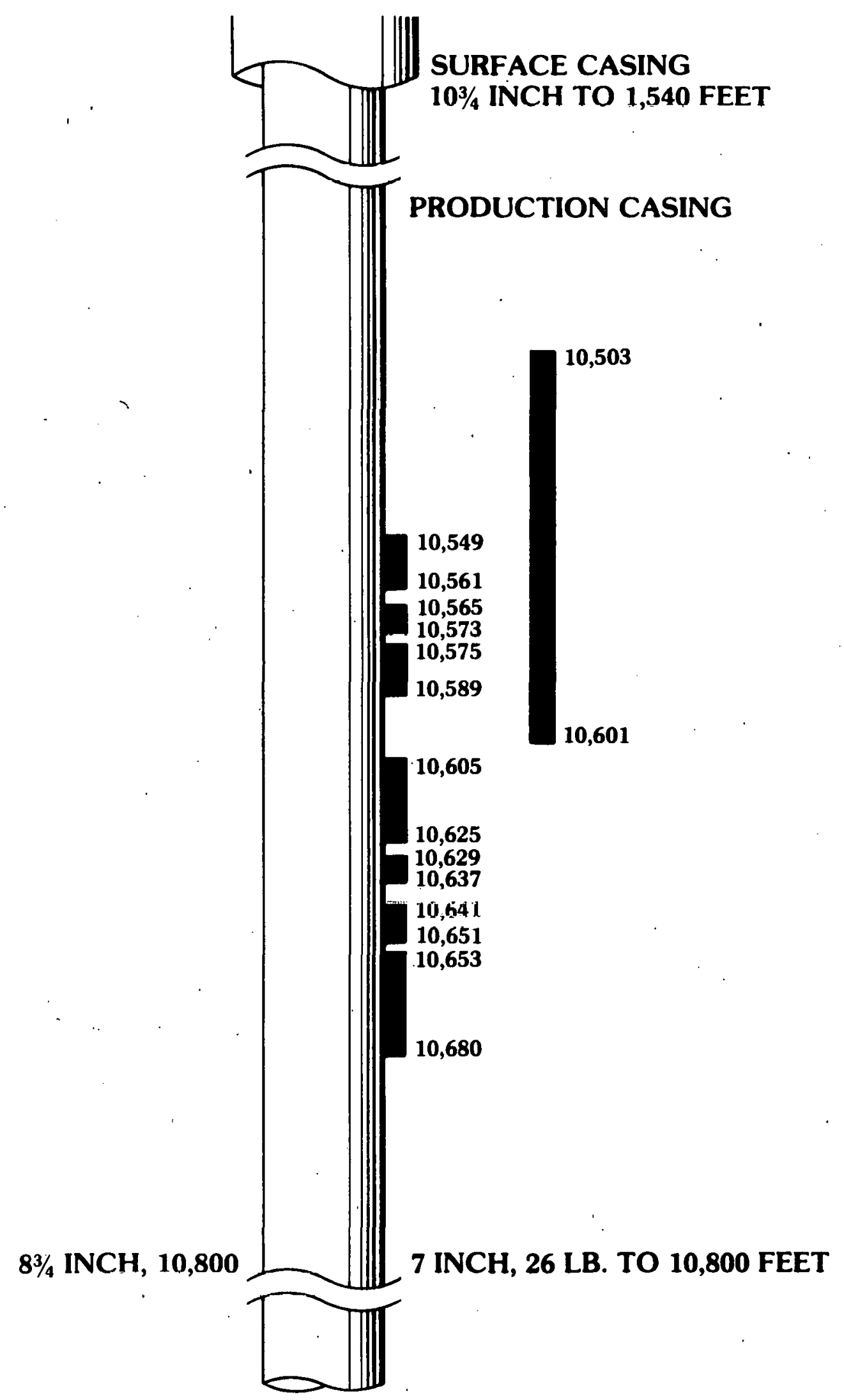

FIGURE 5-6 SCHEMATIC OF MOBIL F-31-13G WELL 


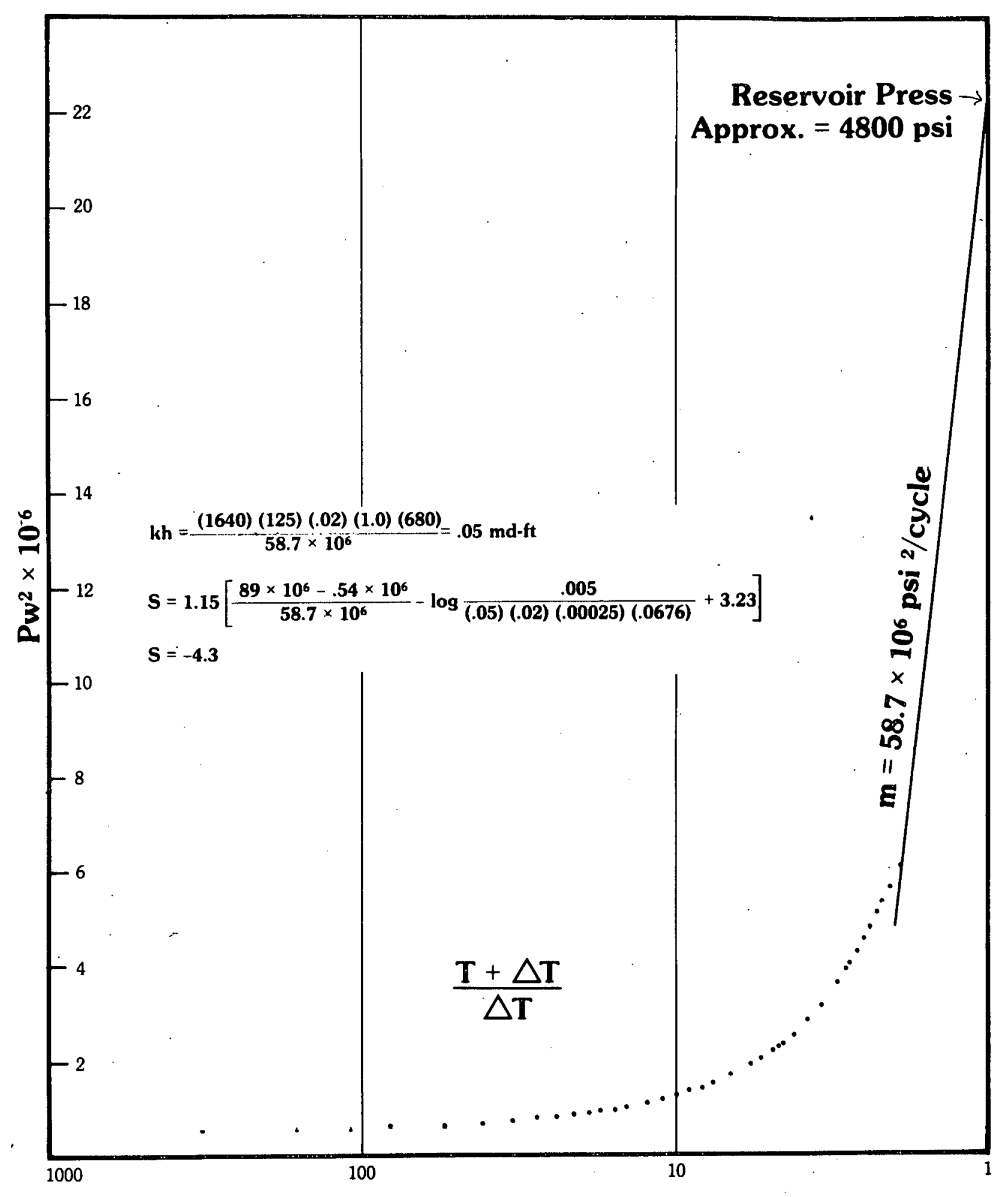

FIGURE 5-7 PCU \#31-13 PBU (BEFORE BREAKDOWN) ZONE 1 


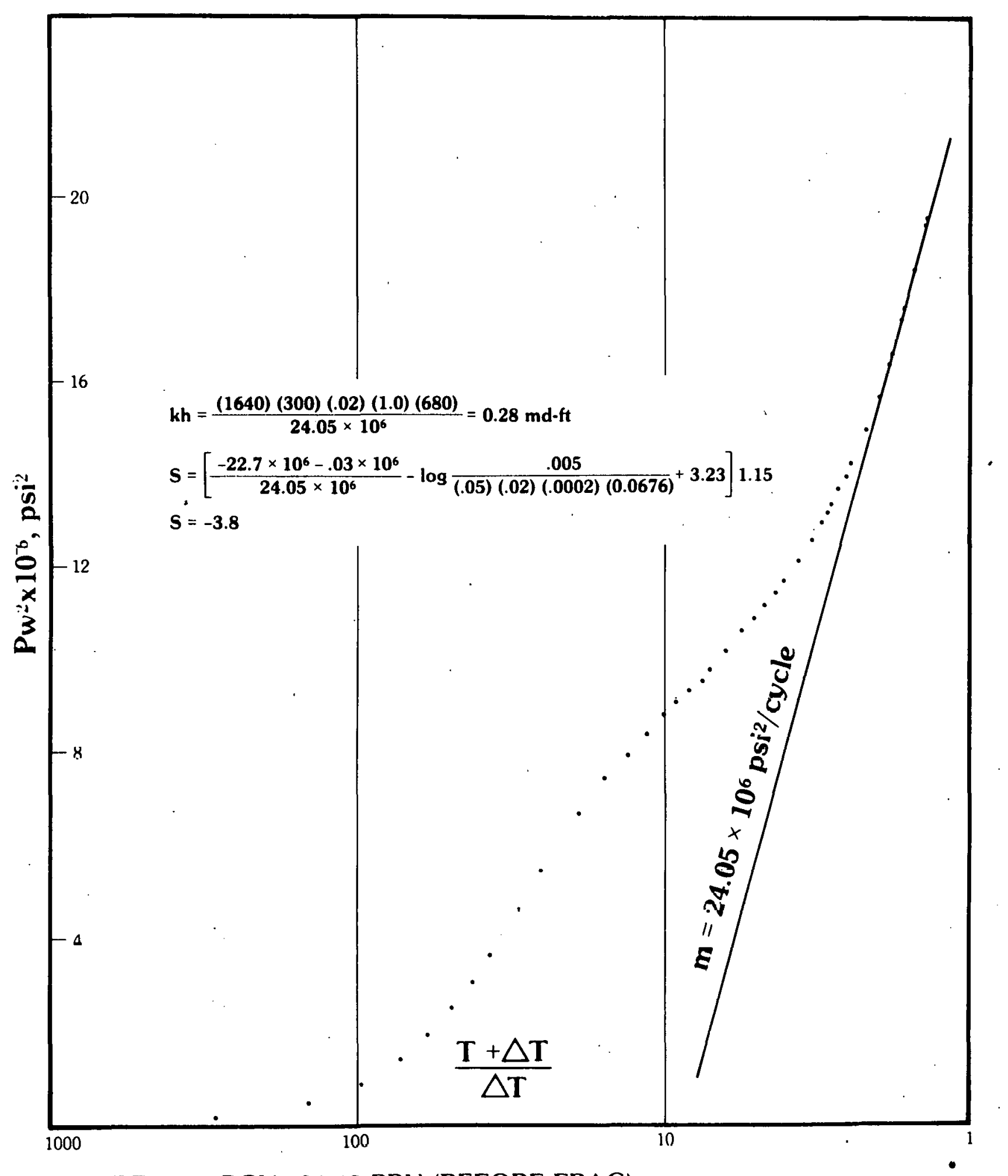

FIGURE 5-8- PCU \#31-13 PBU (BEFORE FRAC) 


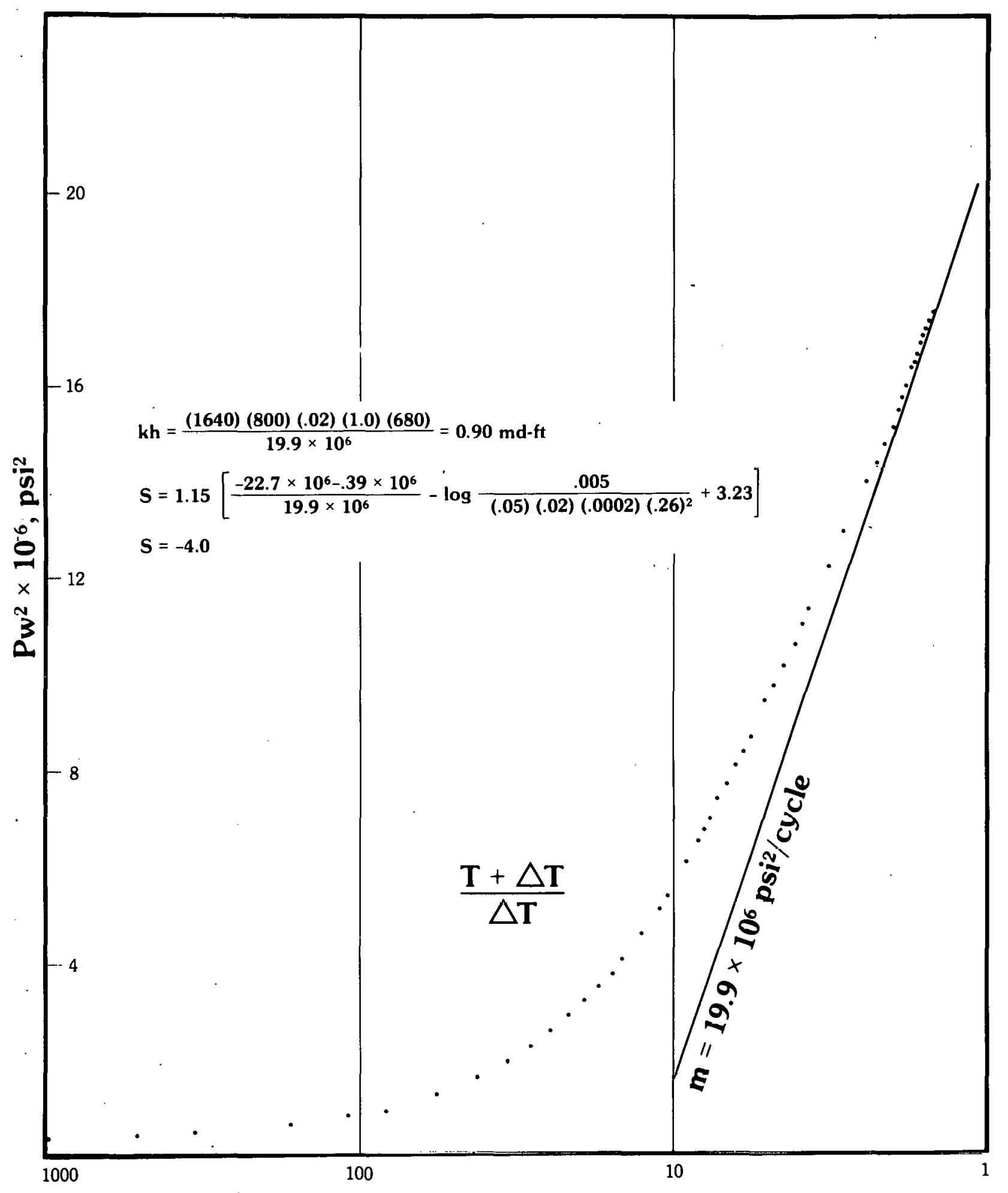

FIGURE 5-9 PCU \#31-13 PBU (AFTER FRAC) 


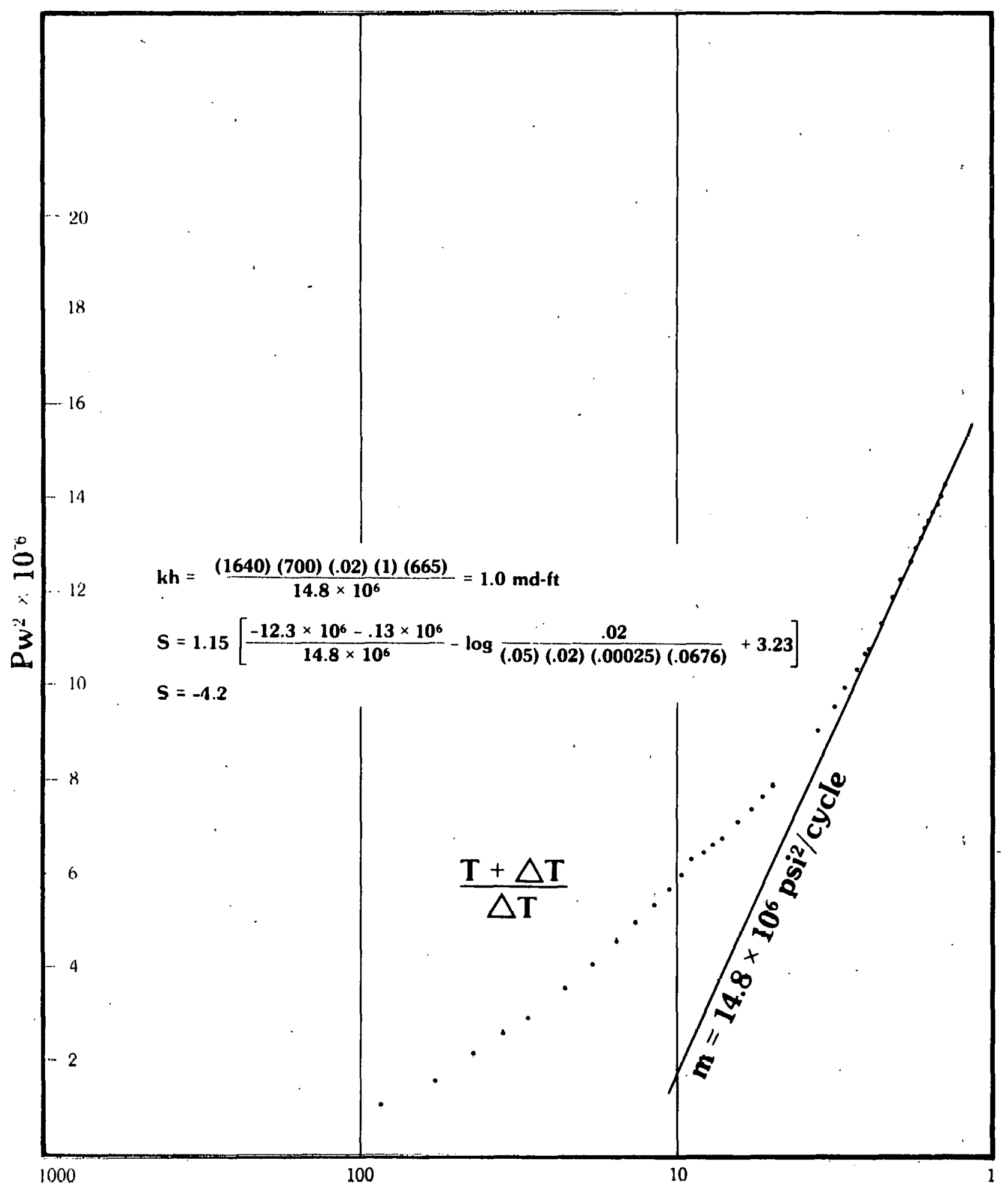

I I ( ; I IRI: 5-10 PCU \#31-13 PBU (BEFORE FRAC) ZONE 3 


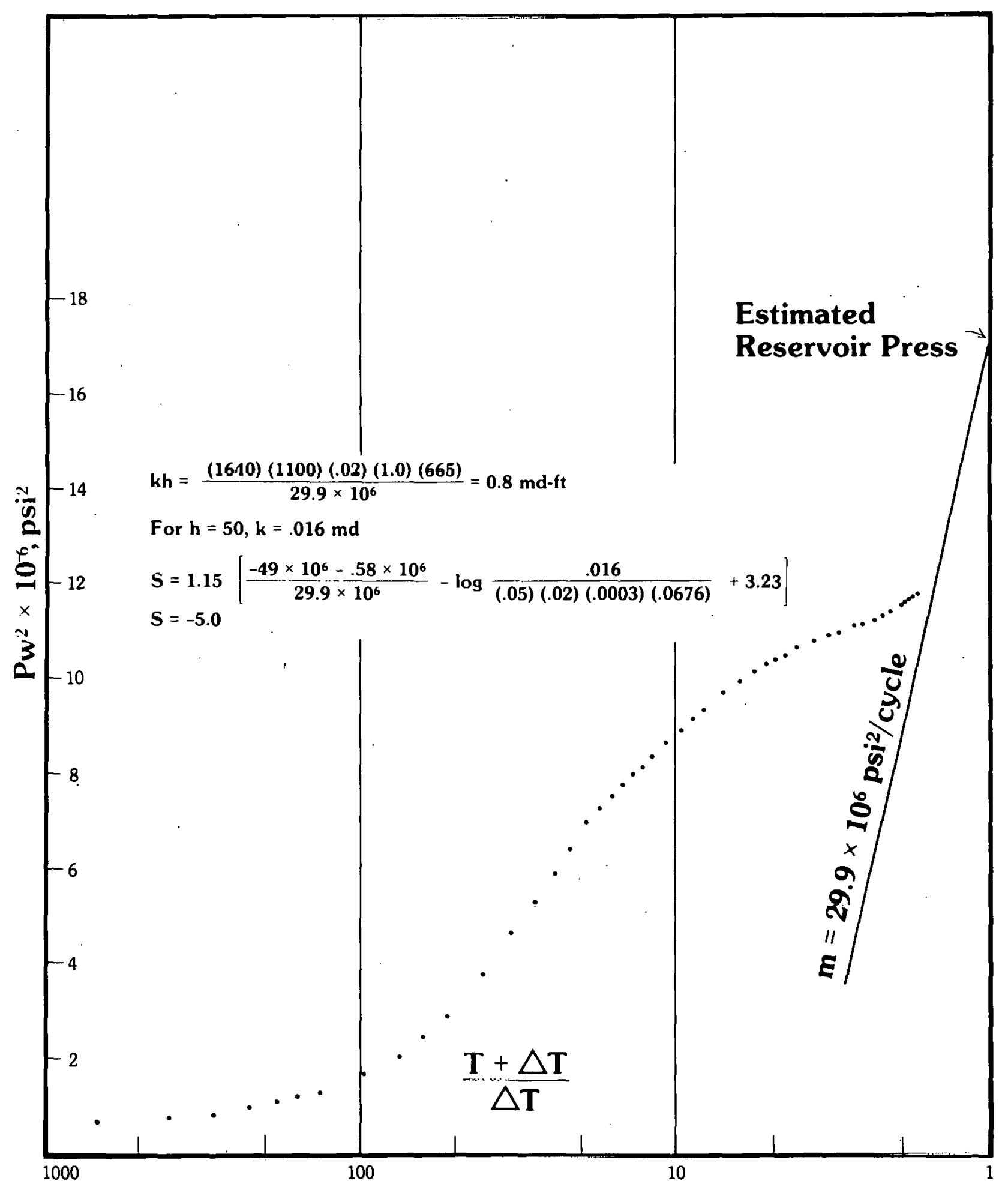

FIGURE 5-11 PCU \#31-13 PBU (AFTER FRAC) ZONE 3 


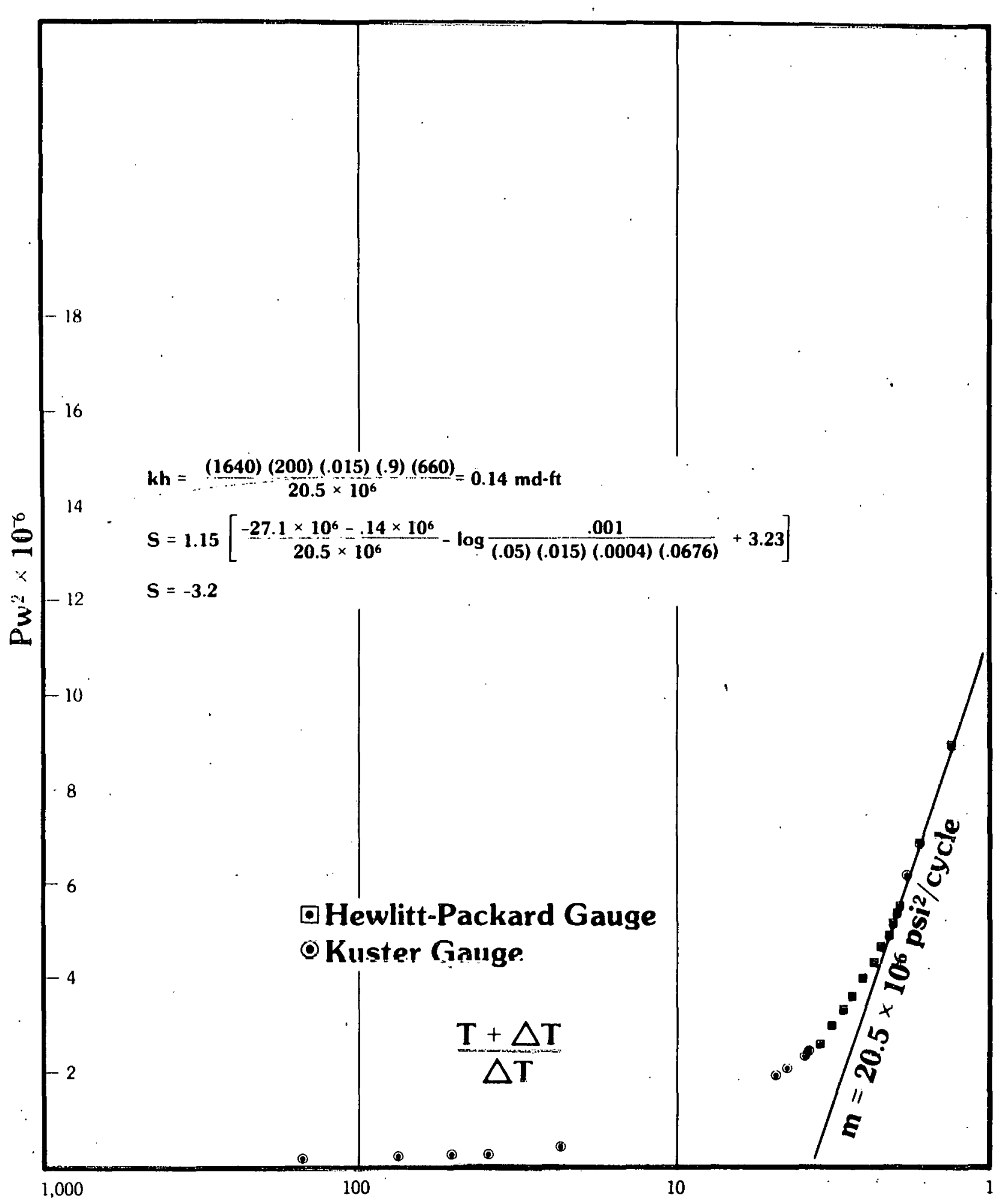

FIGURE 5-12 PCU \#31-13 PBU (BEFORE FRAC) ZONE 4A 


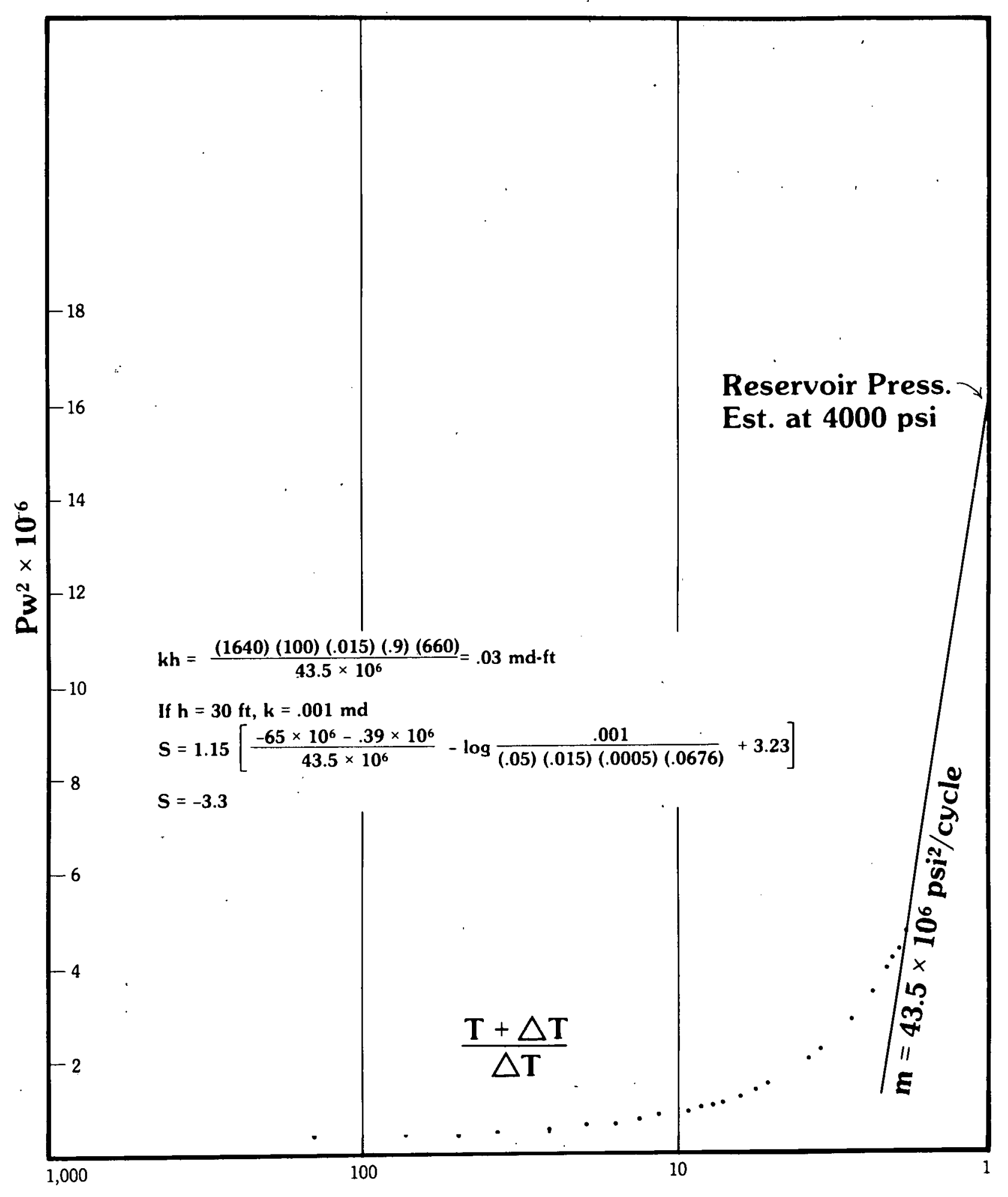

FIGURE 5-13 PCU \#31-13 PBU (BEFORE FRAC) ZONE 4B 
SAND RIDGE AREA, UINTAH COUNTY,

UTAH, MASSIVE HYDRAULIC FRACTURING

EY-76-C-08-0680 DEMONSTRATION

Pacific Transmission Supply Company

San Francisco, California

Status: Project Completed

Final Report in Progress
Contract Date:

Anticipated Completion:

Total Project Cost:

Principal Investigator:

Technical Project Officer:
September 1, 1976

January 31, 1979

DOE ........................ \$495,000

Contractor... 880,000

Total $\$ 1,375,000$

Jack L. Wroble

C. H. Atkinson, Bartlesville Energy

Rescauch Center

\section{OBJECTIVE}

To evaluate the effectiveness of massive hydraulic fracturing for stimulating nat ural gas production from thick, deep, low permeability sandstone formations.

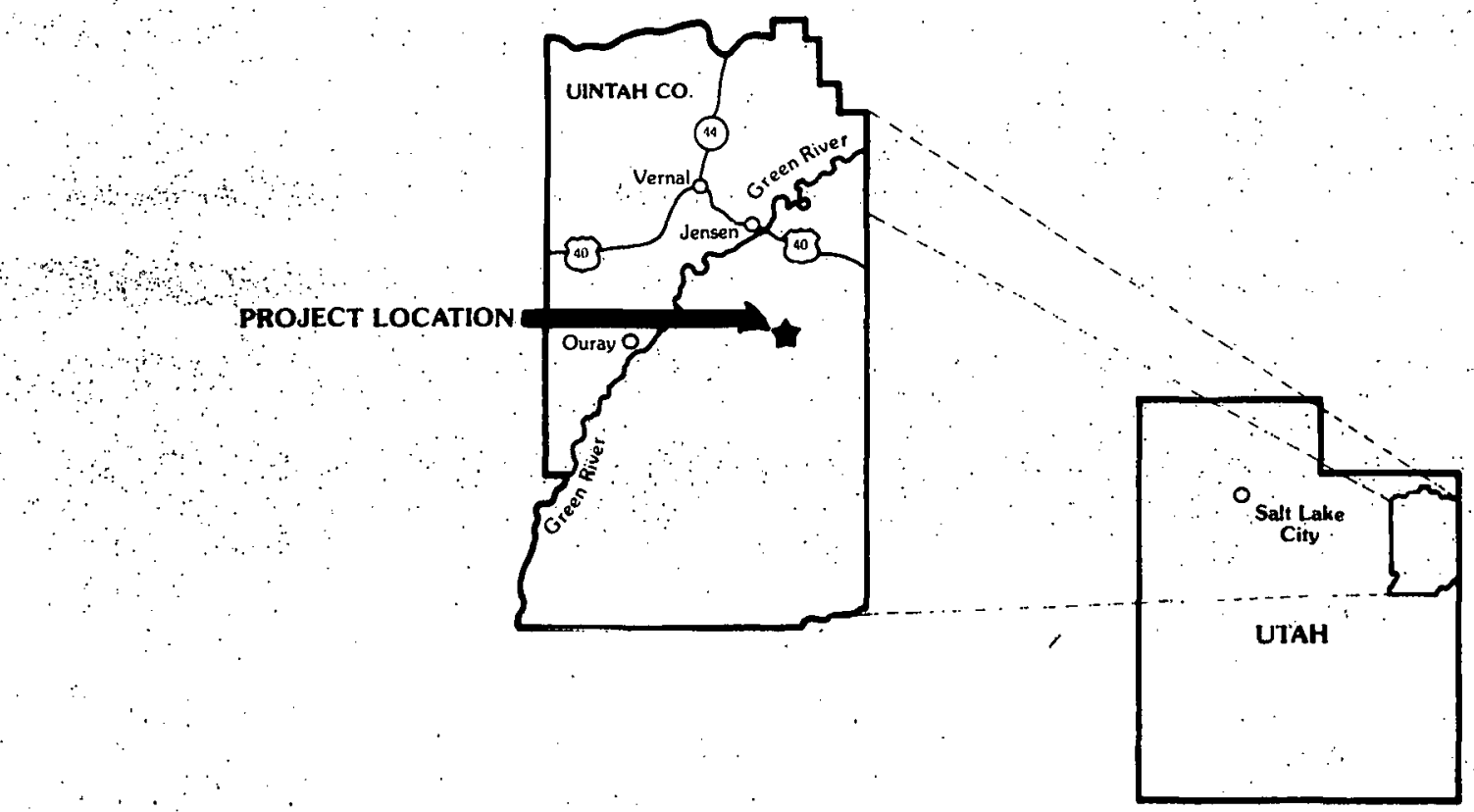


Rio Blanco Natural Gas Company

Status: Active

Denver, Colorado

Contract Date:

Anticipated Completion:

Total Project Cost:

Principal Investigator:

Technical Project Officer:

August 1, 1976

March 31, 1978

DOE ....

Contractor 593,000

Total . . $\$ 1,003,000$

Robert E. Chancellor

C. H. Atkinson, Bartlesville Energy

Research Center

\section{OBJECTIVE}

To evaluale llie eflecliveriess of massive hydraulic fracturing for etimulating natural gas production from thick, deep sandstone reservoirs having extremely low permeability.

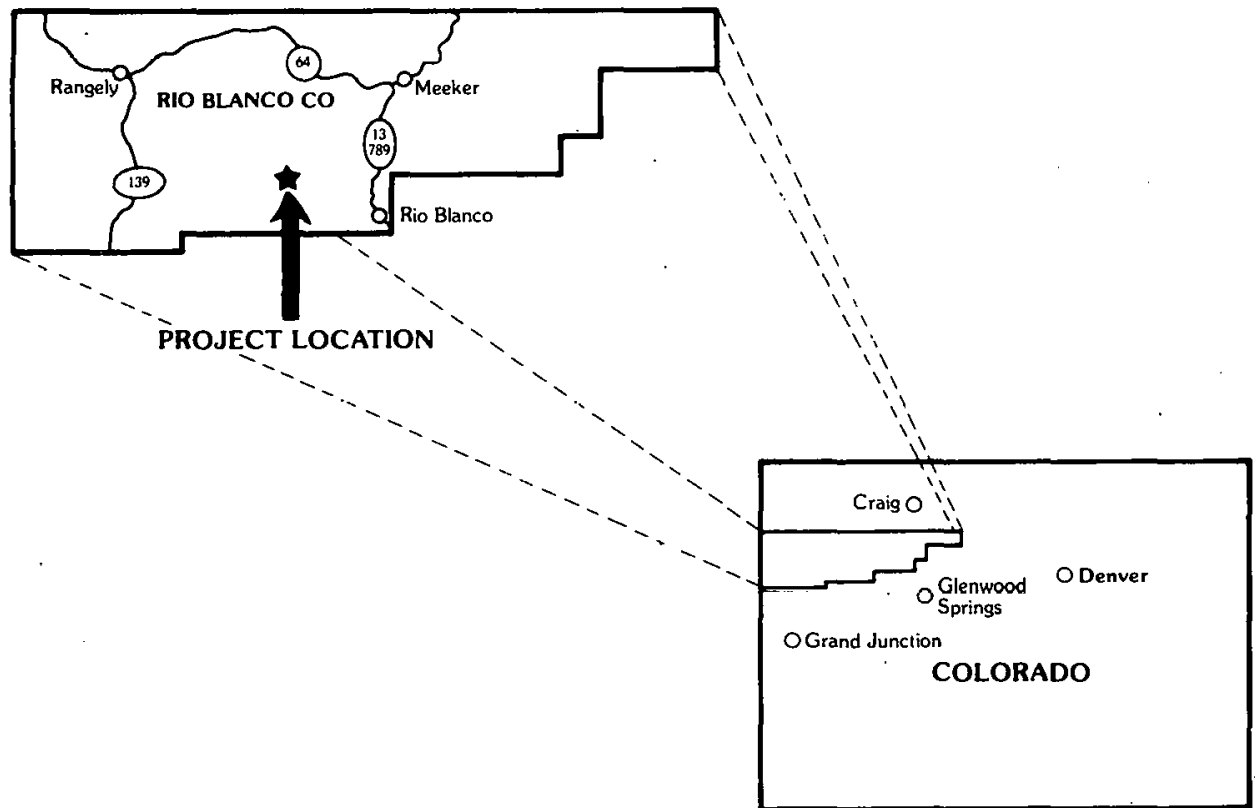




\title{
5.7 Rio Blanco Natural Gas Company
}

\author{
5.7.1 Summary of Past Activities
}

In June 1976, DOE Contract EY-76-C-08-0677 was signed with Rio Blanco Natural Gas Company. The scope of work consisted of preparing an existing well (Federal 498-4-1) for the MHF treatment. This well, located in Section 4, T4S, R98W, Rio Blanco County, Colorado, was drilled and cased to a total depth of $6,963 \mathrm{ft}$ in March 1975. The Mesaverde formation was stimulated in two separate treatments before the contract MHF was performed.

The massive hydraulic fracturing was performed on October 22, 1976 with a total of $276,000 \mathrm{BBL}$. pumped, including sand volume and flush.

\subsubsection{Contract Modifications for an Additional Fracture}

DOE and Rio Blanco Natural Gas Company entered into a supplemental agreement, effective October 1, 1977, to determine whether the previous fracture may have closed due to proppant crushing or whether less gas is available than originally estimated. It was felt that it would be ieneficial to perform an additional racture using 12/20 mesh glass beads, a high strength propping material, mixed with the normally used sand proppant in the latter part of the fracture treatment.

\subsubsection{Current Activities}

On October 26, well service rig no. 3 rigged up and activities commenced with the bleed oft of wellhead pressure. On November 12 , after considerable preliminary work, four intervals were perforated for production with seventeen 0.38 in. to $0.40 \mathrm{in}$. holes. 'the intervals perforated were:

$$
\begin{aligned}
& \text { (1) } 5,960,5,928,5,920,5,910 \\
& \text { (2) } 5,784,5,770,5,748,5,730,5,706 \\
& \text { (3) } 5,330,5,524,5,530,5,492 \\
& \text { (4) } 5,420,5,410,5,402,5,376
\end{aligned}
$$

On November 14, the four perforations in the flrst interval were successfully broken down along with five perforations in the second interval. However, some difficulty was experienced with the second interval and complete ball-out was never achieved. On November 15, the final two intervals were broken down and again, complete ball-out was not attained. 
On November 20 , the vell was flowing 135 MCFD through a $7 / 32$ in. orifice plate, and on November 21 , the average rate was 120 MCFD. Equipment failures, drifting snow and cold weather caused some problems.

\begin{tabular}{|c|c|}
\hline Date & Flow Rate \\
\hline Nov 24 & 38 MCFD \\
\hline Nov 25 & 78 MCFD \\
\hline Nov 26 & 94 MCFD \\
\hline Nov 27 & 75 MCFD \\
\hline
\end{tabular}

Upon completion of the preparations, the MHF was performed on November 30, 1977. Frac details are available in daily reports directed to R. L. Mann, CER Corporation. 